\title{
COLOCANDO A BOCA NO TROMBONE
}

Demonstrar uma abordagem mais ampla da corrupção tornou-se um dos propósitos prioritários desta publicação. Restringir os esforços em matéria de controle às práticas mais comuns, cujos resultados são conhecidamente limitados, é investir em um fundo perdido. Neste tópico, vamos depositar alguma quantia de argumentos na conta da ética cidadã.

Não há dúvidas de que a incansável rotina de escândalos trouxe uma forte sensação de descrença à sociedade. Percebe-se que a maioria das pessoas procura não se envolver com a política, e aconselha que ninguém de bom-caráter o faça, pois acredita ser uma banda inteiramente podre, da qual salvam-se poucos. Não se envolvendo, ela [a sociedade] acaba tolerando e, assim, perde o necessário espírito cívico e a percepção de que pode agir em prol da ética.

E nós - eu que escrevo e você que me lê - bem sabemos que tão logo os cidadãos se convertam em meros espectadores da vida política, pouco a pouco, as ações imorais multiplicam-se e fortalecem-se. $\mathrm{Na}$ linha do que diz a frase atribuída a Martin Luther King: poderemos nos arrepender nessa geração não apenas pelas palavras e ações das pessoas más, mas pelo silêncio assustador das boas. ${ }^{139}$ É sobre isso que falaremos.

139 O restante da citação é tão adequado quanto o seu início, de modo que vale a pena ser completada, ao menos em rodapé: "o progresso humano nunca gira nas rodas da inevitabilidade; vem pelos incansáveis esforços de homens resistentes (...), e sem esse trabalho duro, o próprio tempo torna-se aliado das forças da estagnação social”. 
-• Finanças públicas: travessia entre o passado e o futuro

Não exatamente sobre as pessoas que submergiram nesse estado de anestesia moral, mas sobre aquelas que agem imbuídos de cidadania e colocam a boca no trombone para denunciar o que acreditam não estar em consonância com o correto, moral e ético. São os whistleblowers (whistle $=$ apito; blower $=$ soprador). Não se assuste!

A corrupção costuma ocorrer a portas fechadas e bem distante dos olhos do público. Mas não é difícil dizer quando algo aparentemente está errado - seja pela rachadura na parede de um órgão público, ou ainda pela falta de remédio na prateleira, e quando as suspeitas surgem, existe um modo direto pelo qual uma pessoa pode exercer o seu papel cidadão: falando!

Jeffrey Wigand, um desses sujeitos que se levantou contra a passividade e levou ao conhecimento do público condutas graves de corrupção no âmbito da indústria do tabaco norte-americana, detonando um escândalo de repercussão internacional no setor, contou que a mensagem fundamental de sua história é que: "um indivíduo pode dar um passo à frente e fazer a diferença". ${ }^{140}$

A medida que será analisada agora busca concretizar justamente essa ideia: de que, apesar das forças aparentemente avassaladoras que impulsionam a corrupção, cidadãos individualmente podem tomar uma iniciativa e promover accountability e ética organizacional. No entanto, não é tão simples como parece à primeira vista.

Opor-se à injustiça, à imoralidade, à ilegalidade, nunca foi fácil. Nos momentos mais terríveis da história, soldados submetidos a ordens cruéis de seus superiores, mesmo discordando delas, não conseguiram. Burocratas em regimes autoritários que têm de executar demandas injustas da autoridade máxima, tampouco fizeram frente a elas. Esse tipo de inação [ou falta de reação] não é exclusiva de regimes arbitrários, mas ocorre até hoje em diversas democracias consolidadas, embora de modo diferente. $\mathrm{Na}$ vasta burocracia governamental, é fácil ocultar ilegalidades quando ninguém se apresenta para relatar a verdade.

Quando isso acontece, no entanto, a reação das autoridades ou organizaçôes em relação aos dissidentes, ou seja, àqueles que destoam do grupo ou não se adequam às regras de conduta, não é outra senão o ostracismo, o desprestígio profissional e social, a perda de estabilidade financeira e, principalmente, o risco à integridade física. Romper o incrustado código de silêncio (omertà) acarreta sérios ônus pessoais. Não chega a ser surpreendente, desta forma, que somente uma

${ }^{140}$ JHONSON, Roberta Ann. Whistleblowing: when it works - and why? Lynne Rienner Publishers, 2003. 
pequena parcela de pessoas que testemunham atos de corrupção ou má-gestão em sua entidade, empresa ou órgão, reportem esses acontecimentos. ${ }^{141}$

Para que o leitor tenha ideia de como ocorre a resposta feroz da organização àqueles que soam o alerta sobre fraudes em seu interior, é eloquente a declaração de Bert Berube, engenheiro-civil norte-americano que, na década de 1970, denunciou comportamentos ilegais na Agência de Administração de Serviços Gerais do Governo Federal dos EUA (General Service Administration), onde exercia a função de diretor: "O governo tentou negar o meu seguro-desemprego e gastou, eu imagino, pelo menos 200.000 a 300.000 dólares tentando impedir que eu conseguisse 5.000 dólares do seguro. $\mathrm{O}$ seu objetivo era negar-me quaisquer recursos para que eu desistisse de lutar, independente do custo para o próprio governo. As consequências em relação à minha mulher e filhos foram simplesmente devastadoras". ${ }^{142}$

Lançar o alerta, tornando públicos comportamentos inapropriados é um negócio arriscado. Mesmo assim, alguns indivíduos decidem assumir o risco em prol de um interesse maior. Apesar dos custos e frustrações, essas pessoas assumem voluntariamente o compromisso individual a um propósito ou princípio ético (honestidade, responsabilidade) e resistem às influências imorais para insurgir-se contra a corrupção. Neste conflito ético aparentemente irresolúvel - reportar as ilicitudes, interrompendo-as, e sofrer as consequências pessoais? Ou aquiescer com elas e, assim, implicitamente concordar? - poucos permanecerão no primeiro caminho. Por isso, podemos chamá-los de resistentes éticos.

Sempre que uma irregularidade tem lugar em determinada instituição, algumas pessoas tomam conhecimento de sua ocorrência e, embora sintam-se indignadas, deixam de denunciá-la. Falta pavimentar os meios a fim de assegurar que esses indivíduos não sofram discriminações se ajudarem a revelar e corrigir esses abusos.

Pensar esse sistema que proteja, encoraje e estimule os resistentes éticos é, sobretudo, um ferramental de controle preventivo, uma vez que coloca à disposição

141 Conforme pesquisa realizada em 2016 sobre Ética no Trabalho, pelo Instituto de Ética e Negócios (IBE), em 10 dos 13 países pesquisados, 50\% dos respondentes disseram que reportaram práticas irregulares que presenciaram. Em 11 dos 13 países, pelo menos um entre três respondentes também experimentaram retaliação. Uma relação direta foi revelada: os países com maior índice de denúncia tendem a ser também os com maior grau de retaliação. (Institute of Business Ethics, Survey on Business Ethics, 2016, p. 1. Disponível em: <http://www.ibe. org.uk/userassets/briefings/b56_surveys2016.pdf>. Acesso em: 9 maio 2017).

142 GLAZER, Myron Peretz; GLAZER Penina Migdal. The whistleblowers: exposing corruption in government \& industry. BasicBooks, 1989. 
dos órgãos fiscalizadores informações úteis sobre condutas ilícitas ou antieconômicas, detectadas em primeira mão, ajudando a identificar e desarticular a corrupção de forma prematura, pela raiz. Na receita que até então vamos acumulando à boa-governança, o whistleblowing, ou, a possibilidade de assoprar o apito e denunciar violações às normas legais ou éticas, é um ingrediente essencial. Primeiro, vamos descobrir exatamente quem são estes indivíduos.

Toda organização, seja pública ou privada, está constantemente sujeita ao risco de que alguns de seus integrantes enveredem por um caminho de transgressão à lei e aos valores éticos. É o que nossos olhos mais veem e leem no Brasil ultimamente. Quando esses riscos aparecem, as pessoas mais habilitadas para detectar o problema são aquelas que estão dentro da própria instituição ou empresa. Elas estão melhor posicionadas e conhecem as práticas da organização: participam da rotina da empresa, estão em contato com os outros trabalhadores e superiores, além de conhecerem em detalhe os procedimentos internos. Por conta disso, a informação de que dispõem é extremamente valiosa. Tal como o diamante para alguém que busca pedras preciosas, nada melhor para o controle preventivo do que contar com informação confiável e tempestiva. Aqueles que conhecem internamente a organização certamente terão maior capacidade de detectar fraudes, ineficiências e prevenir danos.

Pense no médico que, ao testemunhar o desvio de recursos direcionados ao hospital municipal onde trabalha, decide reportar essa conduta às autoridades competentes, preocupado em melhorar o atendimento naquela instituição; ou, ain$\mathrm{da}$, no diretor do setor de compras de determinada empresa prestadora de serviços ao poder público, que tenha conhecimento do pagamento de propinas pelo proprietário ao gestor, além do fornecimento de materiais em péssimo estado, denunciando os abusos de seu superior hierárquico.

Podemos dizer, diante desses exemplos, que o reportante - utilizarei esta designação para o restante do capítulo, explicando os motivos logo em seguida consiste no sujeito, trabalhador, empregado ou vinculado de alguma forma a determinada instituição pública ou privada que, voluntariamente e de boa-fé, revela informações de interesse público sobre corrupção, fraude, desperdício, má-gestão ou práticas perigosas consumadas nessas organizações, a autoridades ou órgãos competentes para investigar e atuar contra elas. A partir desse conceito simplificado, já é possível identificar alguns elementos básicos: sujeito, objeto e receptor. Vamos a eles.

O sujeito é o próprio reportante, que sai da inércia para informar sobre condutas irregulares de dentro da organização. Há uma certa variação nos estudos 
sobre o whistleblowing, quanto à determinação sobre quem enquadrar-se-ia neste conceito. Delimitar essa questão é fundamental, pois permitirá estabelecer quem estará circunscrito em eventual programa ou lei que protege o informante de represálias. É possível identificar duas linhas principais: a primeira adota um conceito amplo, alcançando qualquer indivíduo que relata más condutas, independentemente do vínculo com a organização objeto da denúncia. Embora seja saudável o exercício irrestrito da cidadania controladora, me parece que abraçar um grupo tão extenso de potenciais reportantes em um programa específico não é o mais adequado, tendo em vista a possibilidade de gerar obstáculos de difícil superação prática (ex.: contingenciamento do canal de denúncias, inviabilidade de filtragem etc.). É melhor que se adote critérios mais objetivos para definir o reportante na lei. Entendo que a existência de uma relação de trabalho, mercantil ou mesmo contratual com a entidade pública ou privada em questão seja um critério razoável e esclarecedor para classificar os reportantes. Seriam incluídos nesta acepção: empregados ou servidores, fornecedores e demais contratantes, observadores privilegiados do cenário ilícito. Justifico essa restrição: esses são sujeitos que estão mais próximos à organização e, consequentemente, das irregularidades que eventualmente aconteçam em seu interior.

Logicamente, não defendo que sejam ignoradas as demais situações - como as denúncias de cidadãos não ajustados neste conceito - devendo haver vias alternativas eficazes de recebimento e apuração destes relatos.

Outro aspecto importante é a possibilidade de que o sujeito reportante provenha tanto do setor público, como privado. ${ }^{143}$ Em geral, as definições de corrupção limitam-se ao abuso do poder público a fim de obter benefícios pessoais, desprezando o lado oposto da moeda, de oferta da corrupção. Não há corruptos sem quem os corrompa. O conluio no setor privado distorce a livre competição e acarreta o aumento severo de custos. No Brasil, temos observado como as grandes corporaçōes formavam cartéis para atuar em setores específicos, especialmente ligados a obras públicas. Nesses casos, fraudes como a escolha prévia dos vencedores na licitação e o superfaturamento dos preços ocorrem mesmo sem a participação de agentes públicos. Se tiverem compromisso ético-corporativo e um sério programa de integridade, as empresas devem, portanto, se preocupar em estabelecer canais internos para que seus funcionários reportem condutas irregulares, protegendo-os

143 O art. 33, da Convenção das Nações Unidas contra a Corrupção (ratificada no Brasil pelo Decreto n. 5.687/2006) recomenda aos países uma proteção amplíssima em relação a qualquer pessoa, do setor público ou privado, que reporte abusos, de boa-fé, e por motivos razoáveis. 
-• Finanças públicas: travessia entre o passado e o futuro

de retaliação. Deste modo, prevenir-se-ia riscos e danos aos cofres e à reputação da própria organização.

No tocante ao objeto, quer dizer, à delimitação do âmbito material (o que será denunciado?), a situação se inverte. Há quem defenda uma restrição do conteúdo das denúncias a condutas específicas, tal como a corrupção tipificada no Código Penal. No entanto, acredito que a melhor opção seja a não limitação, a priori, dos canais de denúncias, ${ }^{144}$ apenas fomentando a responsabilidade na hora de reportar. Não há matéria específica que desperte a atuação proativa de quem deseje informar más condutas. São situações diversas que implicam em perigo ao interesse coletivo. A experiência de países que já preveem este mecanismo revela episódios que vão desde corrupção e desperdícios de recursos públicos até assédio sexual e prejuízos decorrentes do lançamento irregular de um ônibus espacial pela NASA (caso Challenger).

No entanto, o escopo das denúncias também não pode ser exageradamente aberto, de modo que três condicionantes devem pesar sobre o relato, como forma de qualifica-lo: primeiro, que ele seja relevante, indicando possíveis ou atuais violações graves a determinada norma. Exclui-se, portanto, fatos irrelevantes ou revanchismos que possam comprometer a qualidade das investigações. ${ }^{145}$ Segundo, que o relato seja feito de boa-fé, evitando denúncias maliciosas, cujo conteúdo o reportante saiba ser falso e, por fim, que o reporte seja razoável, no sentido de que as informações descortinadas contenham sentido lógico, de sorte que o interesse público justifique iniciar uma investigação sobre elas. Quanto aos dois últimos elementos, é importante ter uma análise objetiva, sem voluntarismo, de maneira que um terceiro desinteressado, em frente aos mesmos fatos, tirasse conclusões semelhantes sobre a irregularidade. ${ }^{146}$

144 Essa é a recomendação adotada pelo Conselho Europeu em relação aos países da Comunidade Europeia, conforme se afere na Resolução n. 1.729: "6.1. A legislação whistleblowing deve ser compreensiva: (...) 6.1.1. a definição de relatos protegidos deve incluir todos os alertas de boa-fé contra vários tipos de atos ilegais, incluindo todas as violaçôes sérias aos direitos humanos que afetem ou ameacem a vida, saúde, liberdade, ou qualquer outro interesse legítimo de indivíduos como sujeitos da administração pública (...). Conselho Europeu, Resolução 1729 (2010), Final Version Protection of Whistle-Blowers. Parlamentary Assembly.

145 Deve-se, contudo, tomar as precauções para que o feitiço não se volte contra o feiticeiro, de modo que, estabelecendo critérios de gravidade excessivamente altos, ou de pouca frequência na organização, desvirtue a própria finalidade do programa, tornando-o instrumento de pouco efeito prático.

${ }^{146}$ Em geral, as legislações sobre whistleblowing preveem uma presunção relativa de boa-fé referente ao relato do reportante, justificando a proteção de sua identidade, que somente poderá 
O receptor, afinal, é a autoridade competente para receber e apurar essas informaçôes de interesse público (a quem denunciar?), compreendendo organismos especializados, entidades responsáveis pela fiscalização da administração pública ou regulação do mercado, além da mídia e da internet. Em geral, esse aspecto não é determinante para a definição do reportante, mas é adequado para mensurar a eficiência do programa de relatos, isto é, saber se há bons canais institucionalizados de denúncia, que são abertos, seguros, e resolvem os problemas que lhe são apresentados. Caso estes canais não funcionam a contento, o programa como um todo restará comprometido, eis que estarão prejudicados dois pressupostos para o seu funcionamento: a) a confiança de que algo será feito para alterar a cenário ilegal; b) a segurança quanto à proteção contra eventuais represálias. Em geral, competente será a autoridade ou órgão que detenha poderes para apurar os fatos relatados, assim como promover as medidas de proteção ao informante. ${ }^{147} \mathrm{Tal}$ autoridade poderá existir dentro da própria organização (canais internos), em entidades estatais ou independentes de controle (canais externos) ou, excepcionalmente, na mídia. É fundamental estabelecer vias acessíveis, o que ocorrerá a partir das linhas diretas (hotlines), através das quais os funcionários poderão manter contato direto com os destinatários da denúncia, expandindo a passagem da inação ao controle.

ser quebrada mediante comprovação, pelo denunciado, de que o whistleblower sabia da falsidade das informações, ou negligenciou a análise sobre a veracidade delas. Esse quesito, no entanto, ao fundamentar a seleção das informações que serão coletadas, pode gerar algumas dificuldades, transferindo a análise antes para quem relata do que para quem deve ser investigado, ao focar nos "motivos" que levaram o indivíduo a reportar. Por essa possível confusão de elementos e subjugação das informaçōes prestadas sobre os motivos que levaram à denúncia, é que o Reino Unido, em 2013, deixou de incluir a boa-fé como elemento para configuração do whistleblowing.

147 No setor privado, há a possibilidade de que o canal de denúncias seja objeto de terceirização, repassando a atividade de investigação e proteção aos reportantes a uma entidade especializada ou escritório de advocacia. Há algumas boas razóes para crer que este modelo seja um bom caminho para a institucionalização do whistleblowing nas empresas. Primeiro, diminuiria os riscos de contaminação do canal pelas autoridades líderes da empresa, evitando uma subserviência que converter-se-ia, muito provavelmente, em acobertamento dos atos de corrupção praticados no interior da organização. Segundo, facilitaria o resguardo da identidade do denunciante, que poderia contar com um órgão mais independente. Terceiro, traria maior certeza no sentido de que algo seria feito para tentar modificar os procedimentos e a burocracia interna, com vistas a corrigir as más condutas denunciadas. No setor público, essa possibilidade encontra alguns entraves jurídicos. Na medida em que o recebimento de denúncias deve ser uma atividade permanente da administração, reclamaria a realização de concurso público (art. 37, II, da CRFB/88) para o preenchimento dos cargos relativos ao canal. 
Ainda não alcançamos uma definição precisa do termo. Para isso, é relevante também diferenciá-lo de outros institutos jurídicos, a fim de evitar uma confusão conceitual. A propósito, uma das formas de descobrir no que consiste determinado objeto, é saber primeiro em que conceitos ele não se enquadra. Portanto, o reportante não é:

Delator premiado: aquele que firma um acordo de colaboração premiada, com base no art. $4^{\circ}$, da Lei n. 12.850/2013 (Lei do Crime Organizado), tem comprovado e confessado envolvimento nas práticas ilícitas, além de interesse na condenação daqueles a quem ele delata, a fim de ser beneficiado por vantagens legais que atenuem a sua responsabilidade no delito. Para tanto, ele firma um acordo com o Ministério Público, titular da ação penal e cede as informações que forem do interesse destes órgãos, o que estará sujeito à homologação posterior do Poder Judiciário. O reportante, em outro giro, não tem qualquer participação com as irregularidades que são objeto de sua denúncia, seja na condição de coautor, seja como partícipe, além de faltar-lhe interesse em obter benefícios de ordem criminal. No primeiro caso, há uma negociação entre um criminoso e o Estado, ao passo que, no segundo, há uma interação entre o Estado e o cidadão honesto. Apesar destas marcantes distinções, é possível um ponto de convergência no tocante à percepção de deslealdade ao grupo que resulta das revelaçōes feitas por ambos. Nos dois casos, o reportante e o delator, na maioria das vezes, são vistos como traidores ou desleais à organização que integram ou integravam.

Acordo de leniência: servem as mesmas elucidações apresentadas acima, haja vista que este acordo, previsto no Capítulo V da Lei n. 12.846/2013 (Lei Anticorrupção), configura uma espécie de delação premiada para pessoas jurídicas envolvidas em atos de corrupção.Justamente em virtude dessas diferenciações é que a possível tradução do whistleblower no Brasil exige cuidado. Algumas designações que já estão sendo adotadas, inclusive em projetos de lei no parlamento, como delator, justamente por remeterem a outros atores, poderá acarretar problemas conceituais e confusões jurídicas. Essa necessária singularização é a razão pela qual escolhi o termo reportante.

\section{Whistleblower: origem e panorama atual}

A origem do termo whistleblower, no propósito específico de designar esses indivíduos que lançam um alerta sobre más-condutas no âmbito de sua organização, é incerta. Acredita-se que seja uma referência ao juiz em um campo de futebol, que assopra o apito a fim de interromper infrações às regras do jogo. ${ }^{148}$

148 MICELI, Marcia P.; NEAR, Janet. Blowing the whistle: the organizational and legal implications for companies and employees. New York: Lexington Books, 1992, p. 15. 
O nascimento do mecanismo como instituto jurídico, no entanto, ocorreu nos Estados Unidos, ainda no século XIX. Curiosamente, é neste país que o whistleblowing alcançou o mais forte grau de consolidação na cultura social e jurídica. O reportante norte-americano se tornou parte proeminente do vocabulário, cultura e vida organizacional, tendo, inclusive, um dia específico destinado ao seu reconhecimento: 30 de julho. ${ }^{149}$ A sua evolução neste país é marcada por três momentos distintos, que vai da criação à consolidação.

A figura do whistleblower surge nos Estados Unidos com um papel inteiramente dissociado da ética organizacional e prevenção da corrupção. A promulgação do False Claims Act, de 1863, em meio à guerra civil, deu início à concessão de prêmios (15 a 25\%) àqueles que denunciassem fraudes em contratos governamentais. Neste contexto, os cidadãos-reportantes substituíam o governo na vigilância da corrupção, mas movidos mais pela possibilidade de gratificação, do que pelo ímpeto de controle social, de modo que acabaram atraindo a fama de caçadores de recompensa (bounty hunters). ${ }^{150}$

$\mathrm{Na}$ década de 1960, o reportante norte-americano adquire uma nova roupagem, graças à resistência das grandes empresas em cumprir as regulações do governo no mercado, passando a ocultar práticas antigas e nocivas ao interesse público, além do aumento da desconfiança da sociedade na integridade dos agentes públicos, particularmente após o escândalo de corrupção conhecido como Watergate. ${ }^{151}$

149 Conforme a Resolução n. 522/2016, do Senado Americano, que instituiu o Dia Nacional de Apreciação ao Whistleblower.

150 False Claims Act (FCA), vide: U.S. Code, Title 31, Subtitle III, Chapter 37, Subchapter III, $\$ 3729$. Entre 1997 e 1999, quase 1.500 queixas em nome do Estado (qui tam) foram peticionadas com fundamento no False Claims Act, e somente em 1999, recuperou meio bilhão de dólares. A lei, que tem o escopo limitado a fraudes e corrupção relacionadas aos contratos governamentais, ainda vigora nos Estados Unidos: em maio de 2017, o médico Roger Holden apresentou uma queixa em nome do Estado sobre violaçóes éticas e pagamentos irregulares que estavam ocorrendo no Hospital onde trabalha, em Springfield. A ação resultou em restituição de quase US\$34 milhões para os cofres públicos, sendo o reportante recompensado com US \$ 5,4 milhōes. O case: United States ex. rel. Viran Roger Holden v. Mercy Hospital Springfieldf. John's Regional Health Center and Mercy Clinic, No. 15-03283-DGK. Disponível em: <https://www.justice.gov/opa/press-release/file/967481/download>. Acesso em: 26 maio 2017.

151 Um dos mais conhecidos e marcantes casos de corrupção dos Estados Unidos, também foi produto das revelações feitas por um whistleblower. No caso, um informante anônimo, identificado como "Garganta Profunda", forneceu dados cruciais sobre as irregularidades que envolviam o Presidente Richard Nixon, a dois repórteres, Bob Woodward e Carl Bernstein, do jornal Washington Post. 
Estes fatores quebraram o paradigma sobre denúncias internas, fazendo com que aqueles que antes agiam buscando o interesse próprio, passassem a ser percebidos como defensores do interesse público. Compreendeu-se que eles serviriam melhor aos seus próprios interesses se simplesmente virassem as costas e evitassem os perigos do confronto. Neste período, com o aumento do número de denúncias sobre corrupção e fraudes, o instituto foi ganhando legitimidade, a partir do apoio da imprensa, de grupos não governamentais e, especial, do Congresso, que promulgou, em 1978, a Lei de Reforma do Serviço Público (Civil Service Reform Act), a qual marcou o início da proteção legal para agentes federais.

A norma, no entanto, deixou a desejar quanto à proteção dos reportantes contra retaliações, surtindo pouco efeito no aumento das denúncias sobre corrupção. Então, em 1989, o Congresso Americano promulga uma nova legislação, prevendo regime específico para os reportantes em âmbito federal, denominada Lei de Proteção aos Whistleblowers (Whistleblower Protection Act). ${ }^{152}$ Algumas proteções adicionais foram acrescentadas à lei em 1994.

$\mathrm{Na}$ entrada do século XXI, o whistleblower assumiu de vez a condição de protagonista no enfrentamento à corrupção. Movido por uma onda de renovação e promoção da ética nas corporaçōes, o instituto se espalhou no sistema jurídico americano, dando origem a centenas de normas protegendo aqueles que reportassem abusos em setores dos mais diversos, como saúde, segurança, resíduos tóxicos, violação de direitos civis, pureza da água e do ar, abusos a crianças. Além disso, outra revisão foi promovida na lei geral de proteção aos denunciantes federais (WPA), dando origem ao Whistleblower Protection Enhancement Act, de 2012. Para mais, em resposta aos escândalos financeiros nas multinacionais Enron e WorldCom, foram publicadas outras duas leis que deram destaque e regularam sistemas avançados de proteção e recompensa aos reportantes: a Lei Sarbanes-Oxley, de 2002, e a Lei Dodd-Frank, de 2010.

A questão relativa a recompensa como fator de estímulo à formulação de denúncias tem funcionado indiscutivelmente bem no sistema estadunidense.

Essa consolidação interna do instrumento nos Estados Unidos serviu como vitrine ao mundo. Atualmente, o sistema de relatos (whistleblowing) se disseminou

152 Sec. 2. Conclusões e propósitos: (A) Conclusões. - O congresso acha que: 1) Funcionários públicos federais que fizerem as revelações descritas na seção 2302 (b).(8) do título 5, do Código dos Estados Unidos, servem ao interesse público ao ajudar na eliminação da fraude, do desperdício, abuso, e dos gastos governamentais desnecessários; 2) protegendo funcionários públicos que divulgam ilegalidades governamentais, desperdícios, e corrupção, é o maior passo em direção a um serviço público mais efetivo; e (...). 
e encontra regulamentação em boa parte dos países desenvolvidos, visto como ferramenta eficaz na prevenção e detecção da corrupção. Dentre outros, adotam alguma legislação protetiva aos reportantes: Reino Unido (Lei de Revelação de Interesse Público, de 1998), Japão (Lei de Proteção aos Whistleblowers, de 2004), Noruega (Lei do Ambiente Trabalhista, de 2005), Canadá (Lei de Proteção às Revelações de Servidores Públicos, de 2007), Nova Zelândia (Lei de Proteção às Revelações, de 2000). Estudo recente da Organização para Cooperação e Desenvolvimento Econômico (OCDE), reforça essa constatação, ao mostrar que, nos últimos cinco anos, houve mais países adotando legislações protetivas aos reportantes do que na quarta metade do século. ${ }^{153}$

\section{Eficiência: mecanismo de prevenção e aprimoramento ético}

Assim como o leitor conhece melhor dos problemas e inquietações de sua própria casa, os reportantes internos são observadores privilegiados do cenário de irregularidade que se manifesta na instituição pública ou empresa onde trabalham. Em razão disso, é bem provável que eles sejam os primeiros a dar conta das condutas imorais praticadas por seus colegas ou superiores. É intuitivo que eles possam funcionar como um alarme prévio de que algo não está ocorrendo como deveria, permitindo que medidas corretivas sejam implementadas antes que problemas mais sérios apareçam.

Imagine quantos servidores e profissionais ocupantes de cargos técnicos na Petrobras tomaram conhecimento das graves ilegalidades que ali ocorriam, mas decidiram permanecer silentes, pelo medo das consequências pessoais que decorreriam da revelação de informações comprometedoras! Quanto prejuízo aos cofres públicos poderia ter sido evitado se não tivéssemos de ter aguardado um acaso incidir sobre certo lava-jato, que envolvia um potencial operador financeiro desse esquema complexo?

Ao diminuir a capacidade dos corruptos de contarem com o silêncio dos inocentes que estão a sua volta, a proteção aos que alertam sobre irregularidades manifesta-se como ferramenta crucial no controle preventivo e detectivo.

A certeza da punição não é o único fator dissuasório à prática de delitos, embora Cesare Beccaria ${ }^{154}$ tivesse razão neste ponto, mas serve igualmente ao propósito

153 OECD (2016). Commiting to effective whistleblower protection. Highlights, 2016.

154 “(...); pois não se pode duvidar que no espírito daquele que medita um crime, o conhecimento e a certeza das penas ponham freio à eloquência das paixões (...). Não é o rigor do suplício que previne os crimes com mais segurança, mas a certeza do castigo (...)" (grifo nosso). BECCARIA, Cesare. Dos delitos e das penas. São Paulo: RT, 1997, p. 41. 
de inibir a corrupção, a consciência de que os mecanismos de detecção estão em pleno vigor, e que seguramente a conduta criminosa não passará batida aos olhos do controle. A sensação orwelliana de estar sendo permanentemente observado é um elemento preventivo que não pode ser ignorado. Se o observador se levanta contra o ato imoral e torna-o visível às autoridades competentes, tanto melhor.

Permitam-me lembrar da premissa que assentei lá atrás para guiar as medidas de prevenção apresentadas neste livro: além da decrepitude dos valores, o ato desonesto está estreitamente ligado à existência de oportunidades que decorrem de uma governança frágil e de um controle deficiente. Tanto maior for a possibilidade de que alguém assopre o apito e escancare a fraude, menores as chances d'ela ocorrer, ou se agravar. Naturalmente, quanto menor a garagem, mais difícil é estacionar.

Em verdade, proteger o reportante que lança o alerta sobre a corrupção serve a ambas intenções. Por um lado, reforça a noção de boa-administração, ao permitir que os mecanismos de controle atuem previamente à ocorrência ou agravamento do prejuízo. Deste modo, evita-se danos, inibe-se fraudes e os custos da investigação, auditoria ou inspeção são minimizados. Por outro, ainda que não seja possível evitar a ilegalidade, o denunciante pode atuar como peça-chave na investigação judicial e para os demais órgãos de controle, provendo informações que facilitem a responsabilização do infrator, reduzindo as dificuldades probatórias que são inerentes aos atos de corrupção. Na maioria dos casos, o reportante, como agente interno especializado, tem acesso a documentos e dados que, de outro modo, seriam inacessíveis pelos métodos ordinários de investigação. De sobra, a atitude corajosa do denunciante inspira outras pessoas a fazer o mesmo, estimulando uma cultura de cumprimento das regras.

O mais importante, contudo, é o impacto que as revelações exercem na política da organização. A exposição negativa, especialmente no tocante às entidades privadas, força a empresa a mudar os seus procedimentos e adotar padrões mais altos de integridade. Mesmo não tendo controle sobre estes aspectos, o denunciante acaba convertendo-se em poderoso catalizador de mudança na política e nas práticas preventivas da organização.

Como? Fazendo com que a entidade pública ou privada dê mais atenção às áreas problemáticas, buscando evitar futuros desvios que causem semelhante exposição; que procure alternativas ou novas políticas mais eficientes em substituição àquelas que se mostraram corrompidas; mude a forma de implementação das regras e dos procedimentos internos, adequando-se a um padrão mínimo de decência e ética.

Esse forte caráter preventivo do whistleblowing também é sustentado pelas organizações internacionais que buscam desenvolver o sistema de controle e 
enfrentamento à corrupção. No plano de ação dos países que formam o G-20 (2013-2014), por exemplo, reconheceu-se o "valor crucial do insider ao governo e às companhias como um primeiro e geralmente melhor sistema de alarme inicial para os tipos de práticas financeiras precárias, corrupção e falhas regulatórias", estabelecendo que os países que ainda não tivessem normas protetivas, implementassem-nas de acordo com os princípios do Grupo de Trabalho Anticorrupção. ${ }^{155}$

De modo semelhante, a OCDE, no recente relatório de recomendações para combater a corrupção e fomentar a integridade, sugere que, "para promover a prevenção da corrupção no setor público, os membros da OCDE devem implementar as medidas de integridade dos agentes públicos, como proteção aos reportantes.". Ainda de acordo com a instituição: "whistleblowing é crucial não apenas para assegurar integridade nas organizações, mas também para assegurar que o interesse público está protegido". ${ }^{156}$

Essas recomendações não destoam do que diz a ONG Transparência Internacional, que em trabalho específico sobre os reportantes europeus, assentou que estes são "cruciais em jogar uma luz sobre práticas corruptas, dada a sua proximidade à fonte do problema. Muitos escândalos na Europa e em outras partes poderiam ter sido mitigados ou possivelmente prevenidos se whistleblowers tivessem canais para falar com autoridades ou imprensa. (...). Quando funcionam de forma adequada, estes canais facilitam a governança democrática e podem contribuir para uma prévia detecção, prevenção e consequente sanção do ilícito". ${ }^{157}$

No Brasil, não obstante os poucos estudos sobre o whistleblowing convergirem quanto à essencialidade do instituto para a implementação de um programa de prevenção, como fez o Tribunal de Contas da União em seu Referencial de Combate à Fraude e à Corrupçãa ${ }^{158}$ ou o Projeto de Plano Nacional Anticorrupção, da

155 G20 Anti-corruption Action Plan (2013-2014). Disponível em: <http://www.oecd.org/daf/ anti-bribery/G20_Anti-Corruption_Action_Plan_(2013-2014).pdf>. Acesso em: 12 maio 2017.

156 OCDE. High-level advisory group. Report to the OEDC Secretary-General on Combating Corruption and Fostering Integrity, 2017.

157 GORBANOVA, Mariya. Speak up: empowering citizens against corruption. Transparency International, 2015.

158 De acordo com o TCU: "a organização também deve estabelecer procedimentos específicos para prevenir a ocorrência de fraude e corrupção (...), tais como rotação de pessoal e a divulgação de canais de denúncia, incentivando terceiros a registrarem indicações de condutas fraudulentas ou corruptas envolvendo a organização ou pessoa relacionada a ela" (grifo nosso). TCU, Referencial de Combate à Fraude e à Corrupção (2017), p. 59. 
FGV,${ }^{159}$ não houve desenvolvimento legislativo dessa matéria por aqui. Pois é. Apesar do sucesso e eficácia dos canais de denúncia pelo mundo, inexiste qualquer proteção legal brasileira às pessoas que iluminam o esconderijo onde ocorre a corrupção e o desperdício. Volte algumas páginas e responda: quanto prejuízo teríamos mitigado ou evitado?

Essa ausência de norma, no entanto, não impediu que algumas poucas pessoas tivessem a coragem e determinação de ajudar o estado no controle de fraudes, mesmo que não lhes fosse garantida proteção adequada. Algumas investigações já foram desencadeadas e episódios de corrupção desvelados a partir de informações providas por funcionários.

\section{Whistleblowing - implementação no Brasil como instrumento de combate à corrupção}

Não é impossível encontrar no complexo emaranhado de leis e decretos brasileiros algum dispositivo que faça referência aos relatos internos, porém nunca de maneira específica, senão de forma esparsa, incompleta, o que não significa muita coisa. ${ }^{160} \mathrm{O}$ art. $7^{\circ}$, VIII, parte final, da Lei n. 12.846/2013 (Lei Anticorrupção ou Lei da Empresa Limpa), por exemplo, que trata da responsabilização administrativa e civil de empresas, prevê a possibilidade de atenuar a aplicação de punições administrativas caso a pessoa jurídica demonstre que havia adotado mecanismos e

159 De acordo com a FGV: "existem, entretanto, dois instrumentos de grande importância cujos estudos merecem ser conduzidos para verificar possível a adoção no framework brasileiro de combate à corrupção: regulação da atividade de lobby e regulamentação do whistleblowing (...), são responsáveis por dar publicidade e moralidade à relação entre políticos e defensores de interesses particulares e por fornecer um sistema adequado para denúncia de irregularidades". Dentre as recomendaçôes apresentadas pela instituição concernentes à "Complementação da estrutura legislativa de combate à corrupção: (i) sistemas de proteção ao denunciante, nos âmbitos público e privados". In: MOHALLEM, Michael Freitas; RAGAZZO, Carlos Emmanuel Joppert (Coord.). Diagnóstico institucional: primeiros passos para um plano nacional anticorrupção. Rio de Janeiro: Escola de Direito do Rio de Janeiro da Fundação Getúlio Vargas, 2017.

${ }^{160}$ Há quem atribua ao art. $74, \$ 2^{\circ}$, da $\mathrm{CRFB} / 88$, o caráter de base normativo-constitucional ao whistleblower no Brasil, ao possibilitar a denúncia de qualquer cidadão perante o Tribunal de Contas. No entanto, conforme a delimitação conceitual realizada anteriormente, viu-se que o consenso quanto à definição do reportante não abrange um espectro tão amplo de pessoas, mas aqueles que possuem vínculo trabalhista, financeiro ou contratual com a organização do setor público ou privado, de modo que não entendo correto afirmar que o art. $74, \$ 2^{\circ}$, faça referência a esta possibilidade, senão à realização de denúncias normais perante à administração, como manifestação do direito fundamental de petição (art. 5º XXXIV, a, CRFB/88). 
procedimentos internos de integridade, dentre eles, o incentivo à denúncia de irregularidades. Outras abordagens normativas, como a prevista na recente Lei n. 13.303/2016 (Lei das Estatais) e na Lei n. 8.112/92, mantém o caráter setorial. Tais previsões fragmentadas, calcadas em conceitos indeterminados, são incompletas, justificando a necessidade de uma regulamentação específica para os reportantes.

Embora seja a parte mais sensível do problema, a falta de um diploma normativo que garanta a confidencialidade e impeça discriminaçôes injustificadas contra os reportantes-internos, não é único impedimento à resistência ética no Brasil. Outros fatores contribuem igualmente para a quantidade cada vez menor de pessoas que se disponham a agir contra o interesse de corruptores: falta de incentivos estruturais localizados; insistência na manutenção do status quo; ausência de grupos de interesse público que reivindiquem ações em favor dos whistleblowers, além dos fatores culturais.

Pelo que vimos até aqui, não é difícil deduzir que o risco de corrupção é significativamente maior onde o ato de denunciar autoridades não é estimulado. Sem incentivos institucionais que sobreponham ou pelo menos equiparem-se ao medo de represálias, é improvável a sua ocorrência. É também um tanto irônico que, em nosso país, incentivemos com tanto vigor os envolvidos na atividade criminosa para que confessem e entreguem os seus comparsas, firmando um acordo de colaboração premiada que implique a renúncia parcial em punir esse infrator, ao invés de pavimentar o caminho para o relato de boa-fé daqueles que não integram o círculo imoral e decidem proteger o interesse público.

Um diagnóstico institucional publicado em 2017 pela Fundação Getúlio Vargas evidencia essa negligência. ${ }^{161}$ Os pesquisadores da instituição dirigiram-se aos portais de acesso à informação de 26 prefeituras de capitais brasileiras com os seguintes questionamentos: "Este órgão possui algum programa de proteção a denunciantes internos (funcionários da prefeitura)? Este órgão possui mecanismos de denúncia externa (para pessoas de dentro ou fora da prefeitura)?”. Do total de perguntas, 56\% foram respondidas e $44 \%$ das respostas foram consideradas precisas, isto é, continham uma explicação clara, objetiva e simples sobre o problema perguntado. Ocorre que essa taxa relativamente alta de precisão se deveu ao fato de que $100 \%$ das prefeituras responderam que não possuem programa de denunciantes. ${ }^{162}$

161 MOHALLEM, Michael Freitas; RAGAZZO, Carlos Emmanuel Joppert (Coord). Diagnóstico institucional: primeiros passos para um plano nacional anticorrupção. Rio de Janeiro: Escola de Direito do Rio de Janeiro da Fundação Getúlio Vargas, 2017.

162 Além disso, sete prefeituras responderam que, não obstante não terem programas de proteção ao reportante, possuíam canais para denúncia anônima, em sua maioria por intermédio de ouvidorias. 
- Finanças públicas: travessia entre o passado e o futuro

Outra dificuldade especialmente séria é a existência de grupos que prezam e lutam - se necessário - pela manutenção do estado de coisas. Assim, uma vez que a revelação de condutas fraudulentas frequentemente aclara um quadro sistêmico de irregularidades que já vinham ocorrendo em determinada instituição, os esforços para promover reformas éticas provavelmente serão rejeitados por quem "tira o seu" dos arranjos atuais.

Há ainda um fator que, embora não esteja ligado a quem caiba diretamente implementar as medidas para o whistleblowing, também dificulta o seu desenvolvimento no Brasil. É que não existem organizações não governamentais de interesse público, gestados pela sociedade civil, que busquem pressionar as autoridades para aprovação de reformas estruturais e da legislação protetiva. Organizações como o The Government Accountability Project (GAP), que desempenhou um papel essencial no desenvolvimento dos programas de whistleblowing nos Estados Unidos, e o Public Concern at Work (PCaW), do Reino Unido, demonstram a importância destes grupos no encorajamento, suporte jurídico e psicológico, e, inclusive, financiamento daqueles que pretendam informar práticas corruptas em sua organização. Não é exagero afirmar que sem a participação destas entidades, o programa de proteção aos reportantes, mesmo instalado, restará incompleto.

Todos esses fatores contribuem decisivamente para a permanência do estado de omissão legislativa em matéria de proteção a relatos de interesse público no Brasil. Olhando para o Poder Legislativo, nota-se que falta vontade política em desenvolver um programa nesse sentido, haja vista a quantidade de projetos de lei, tramitando no Senado Federal e na Câmara dos Deputados, que visam regulamentar o whistleblowing nacionalmente, mas que se mantêm resguardados nos escaninhos do parlamento.

Somente no intervalo de 2015 a 2016, quatro projetos de lei foram registrados sobre a matéria. ${ }^{163}$

163 PL n. 3.165/2015, de autoria do Deputado Onyx Lorenzoni (DEM/RS), que institui o "Programa de Incentivo à Revelação de Informações de Interesse Público", pelo qual se prevê medidas de proteção e compensação da pessoa que, de boa-fé, em prol do interesse público, proceda à revelação de informações de que tenha conhecimento; PL n. 97/2016, de autoria do Senador Randolfe Rodrigues (REDE/AP), cujo objetivo é dar confidencialidade aos relatos; PL n. 57/2016, de autoria do Senador Jorge Viana (PT/AC), que institui, no âmbito do CADE, o acordo de colaboração com pessoas físicas que, forneçam informaçôes e documentos que comprovem a infração noticiada ou sob investigação e identifiquem os envolvidos na infração, além de prever uma "gratificação financeira" em favor do que denomina colaborador, na ordem de $0,1 \%$ a $3 \%$ sobre o valor das multas aplicadas pelo CADE. Além desses projetos mais recentes, outras propostas de conteúdo semelhante já existiam, como o PL n. 1.701/2011, de autoria do Deputado Carlos Manato; e o PL n. 664/2011, do Senador Walter Pinheiro. 
Vale destacar a presença do reportante (denunciante) no PL n. 4.850/2016, referente às "10 medidas contra a corrupção", precisamente nos arts. 38 e 39, estipulando que o terceiro que, não sendo réu na ação penal correlata, espontaneamente prestar informações de maneira eficaz ou contribuir para a obtenção de provas em casos de corrupção, fará jus à retribuição de até $5 \%$ do produto obtido na apuração dos delitos. Nos debates e subsequente votação do projeto na Câmara dos Deputados, as disposições referentes ao whistleblowing foram suprimidas do texto original. Após severas críticas da imprensa e da sociedade em geral de que o Poder Legislativo havia desvirtuado completamente o conteúdo do projeto, o Supremo Tribunal Federal, por decisão de seu Ministro Luiz Fux, concedeu liminar no Mandado de Segurança n. 34.530/DF, em 14 de dezembro de 2016, determinando o retorno do PL n. 4.850/2016 à estaca zero na Câmara dos Deputados, desconsiderando todas as deliberações e a votação que já haviam ocorrido. Os parlamentares terão uma valiosa segunda chance de avaliar essa questão. Que se discuta com maior seriedade a proteção aos reportantes, para que não se perca novamente a oportunidade de implementar ferramenta tão importante de controle.

A propósito, isso não é algo que deveria estar condicionado exclusivamente à vontade política dos congressistas, tendo em vista os vários compromissos firmados expressamente pelo Brasil, em diversas Convenções e Tratados Internacionais de combate à corrupção, no sentido de implementar medidas de proteção e incentivo aos relatos de interesse público. A ratificação desses documentos internacionais confere-lhes status de lei ordinária, ${ }^{164}$ ao lado dos atos normativos primários, de modo que não se trata de meras orientaçôes ou conselhos sem nenhum valor jurídico. Assim, desde 2002, quando o governo brasileiro ratificou a Convenção Interamericana Contra a Corrupção, a partir do Decreto n. 4.410/2002, está comprometido a estabelecer medidas destinadas a criar, manter e fortalecer "sistemas para proteger funcionários públicos e cidadãos particulares que denunciarem de boa-fé atos de corrupção, inclusive a proteção de sua identidade, sem prejuízo da Constituição do Estado e dos princípios fundamentais de seu ordenamento jurídico interno".

De modo semelhante, ao referendar a Convenção das Nações Unidas contra a Corrupção (Convenção de Mérida), através do Decreto n. 5.687/2006, se dispôs

164 “(...) os tratados internacionais, uma vez incorporados ao ordenamento brasileiro, se equiparam às leis ordinárias, não tendo nenhuma preponderância sobre estas. Considerando essa paridade hierárquica, dirime-se o conflito entre tratados internacionais e leis federais pelos critérios cronológico e da especialidade" (ADI n. 1.480, Rel. Min. Celso de Mello, j. 04.09.1997). 
"incorporar em seu ordenamento jurídico interno sistemas apropriados a proporcionar proteção contra todo trato injusto às pessoas que denunciem ante as autoridades competentes, de boa-fé e por motivos razoáveis, quaisquer feitos relacionados a delitos de corrupção".

\section{Fundamentos jurídico-constitucionais do Whistleblowing}

Até aqui, apresentei argumentos pragmáticos (eficácia como mecanismo de controle preventivo da corrupção e aprimoramento ético das organizaçōes) e formais (compromisso firmado em convenções internacionais) em favor de um roteiro que conduza o whistleblowing definitivamente para a agenda brasileira de controle. É possível, contudo, tendo em mente o público irrestrito a quem este livro se dirige, que determinados leitores não estejam convencidos acerca das justificativas, do ponto de vista do direito, que sustentem essa novidade no ordenamento jurídico nacional. Desejosa de que não restem espaços vazios, nem experiências incompletas, apontarei os argumentos jurídicos que fundamentam a medida aqui proposta.

Em primeiro lugar, deve-se entender o direito dos cidadãos de reportar atos violadores das normas legais ou éticas como extensão ou manifestação típica do direito à liberdade de expressão, ${ }^{165}$ conforme consagrado no art. $5^{\circ}$, IV, da Constituição Federal de 1988. É a simples e incontestável liberdade de pensar e dizer o que se crê verdadeiro. ${ }^{166}$ Por conta disso, não é legítimo impor - ou tentar impor - qualquer espécie de restrição ao cidadão, funcionário de determinada entidade do setor público ou privado, que soe o alerta e informe sobre a prática de atos imorais que afetem o interesse da coletividade (art. 220, da CRFB/88). O relato acerca da ocorrência de corrupção, fraude, má-gestão ou atividades nocivas constitui, além de um direito a ser protegido, uma atitude a ser estimulada.

Ademais, ao jogar luz sobre informações de interesse público, que de outro modo ficariam guarnecidas na escuridão em meio à qual os agentes corruptos atuaram, o reportante está pondo em prática o direito à liberdade de informação que lhe garante o art. 50, XIV, da Constituição. A informação aqui compreende o conhecimento de fatos, acontecimentos, e situaçôes de interesse geral, que aponta para duas direções: o direito de informar e o direito de ser informado, cabendo ao whistleblower a realização plena do primeiro. Porém, a sua atitude também resvala

165 Transparência Internacional (2013), International Principles for Whistleblower Legislation: Best Practices for Laws to Protect Whistleblowers and Support Whistleblowing in the Public Interest, p. 2.

166 SILVA, José Afonso da. Curso de direito constitucional positivo. 24. ed. São Paulo: Malheiros, 2005 , p. 241. 
no segundo, já que informações governamentais devem estar sempre disponíveis ao escrutínio do público. A Corte Europeia de Direitos Humanos, no caso Guja v. Moldova, registrou apoio a esse entendimento ao afirmar que "em um sistema democrático, os atos ou omissões governamentais devem estar sujeitas ao escrutínio não apenas das autoridades legislativas ou judiciais, mas também da mídia e da opinião pública". Neste aspecto, reportar corresponde ao direito de abrir os olhos da população sobre corrupção em determinada organização onde o segredo e o mistério sobrepõem os demais valores.

O próprio inciso XIV, do art. $5^{\circ}$, complementa a garantia de acesso, ao proteger o sigilo da fonte de informação, quando necessário ao exercício profissional. É nesta parte final do dispositivo que se encontra a justificativa jurídica para o tratamento confidencial - analisado mais à frente - que deve ser dispensado ao reportante, lhe resguardando de possíveis retaliaçōes ou discriminações injustificadas que possam afetar o exercício de sua profissão. Por esse ângulo, nos EUA, reconhece-se o privilégio da confidencialidade como direito potestativo do governo (como autoridade a quem cabe receber os relatos de corrupção e investigá-los), ao sigilo da fonte quanto à identidade daqueles que lhe informam sobre condutas criminosas ou irregulares, conforme depreende do caso Roviaro $v$. United States. ${ }^{167}$

Deve-se levar em consideração ainda a dificuldade inerente em produzir provas concretas sobre atos corruptos, vez que estes costumam ocorrer em contextos obscuros, especialmente quando praticados dentro da estrutura de governo, onde a burocracia ajuda a jogar a fraude debaixo de um tapete de formalidades. Nesse cenário pouco transparente, é provável que o reportante seja o único meio pelo qual os órgãos de controle tomarão conhecimento a respeito das falcatruas, antes que ela assume proporções de um escândalo.

Enfim, para que esta parte estritamente jurídica não fique mais extensa do que o desejável, não podemos deixar de consignar que a atitude do indivíduo que abandona a posição de espectador diante da corrupção, e levanta a voz a fim de colaborar ativamente com o Estado no enfrentamento da indecência e da má-gestão, dá uma amostra incontestável de cidadania participativa e exercício do controle social, além de promover um incremento institucional significativo, garantindo maior transparência, abertura, e controle na atuação das organizações. O sacrifício pessoal encarado voluntariamente pelo reportante acrescenta muito ao desenvolvimento

167 DALLAGNOL, Deltan Martinazzo. Informantes confidenciais e anônimos: perspectivas para atuação mais eficiente a partir de uma análise comparativa do tratamento jurídico nos EUA e no Brasil. In: Ministério Público e princípio da proteção eficiente. São Paulo: Almedina, 2016. 
ético da sociedade, oxigenando uma república em decomposição, como uma lufada de ar fresco em um ambiente fechado.

Até aqui, espero não ter deixado dúvidas de que o whistleblowing é uma medida a um só tempo eficaz, adequada e constitucional de controle preventivo. É uma proposta que deve ser considerada, para ontem!

Agora, olhando para o amanhã, o que é necessário para que o Brasil dê este passo - para frente - em matéria de controle? Dois cenários se manifestam: um primeiro, relativo à questão cultural (de valores), considerável à longo prazo e que independe de medidas concretas, o qual limitar-me-ei a examinar como uma observadora da realidade; e um segundo, referente ao desenvolvimento de uma política efetiva, tido em curto ou médio prazo, o qual depende de medidas concretas, onde terei a chance de oferecer contribuições e propostas a serem implementadas. Os procedimentos de denúncias são apenas parte de um pacto maior de regras e atividades culturais necessárias para mover a sociedade a um padrão mais aberto.

\section{Mudança cultural}

O primeiro cenário consiste na mudança cultural, ainda extremamente desfavorável aos resistentes éticos. Aqui vai uma pequena história, que retrata um diálogo que tive há pouco tempo com um amigo, em uma conversa desinteressada sobre o assunto. O contexto geral do diálogo era justamente a ética no serviço público, e as possíveis formas de contornar esse cenário pavoroso de lástima moral que vivemos atualmente. Comentei a respeito deste mecanismo inovador, cuja aplicação é tradicional nos Estados Unidos e em outras democracias ocidentais, mas ainda carece de previsão no Brasil, que protege e concede incentivos financeiros para que os funcionários de determinada empresa reportem os atos de corrupção, desvio e desperdícios que eventualmente presenciem no âmbito da empresa ou entidade pública onde exerce suas funções. Expus com certo entusiasmo como esta ferramenta tem sido útil nos países onde é adotada, recuperando boa quantia de recursos desviados e rendendo fartas recompensas aos "assopradores de apito" (utilizei a própria tradução, para não causar espanto), percebendo que simultaneamente a minha fala, o amigo-interlocutor balançava a cabeça com certa incompreensão. Após o término de minha sumária explicação, este colega, depois de alguns segundos franzindo as sobrancelhas, me disse considerar perigosa esta forma de "deduragem" na organização, e que talvez seria mais aconselhável ao funcionário em questão que apenas "faça o seu trabalho" de maneira eficiente, sem questionar aquilo que escape ao âmbito de suas estritas competências. Não concordei com tal 
lógica desvirtuada e absolutória do tipo "faça o seu que eu desvio o meu”, embora em prol da amizade e da boa convivência tenha apenas acenado e por ali encerrado aquele assunto.

O breve relato retrata um pensamento que não é restrito ao meu interlocutor. Por incrível que pareça, essa visão deturpada da dissidência ética nas organizações públicas e privadas é geralmente encarada como uma forma de traição ou, em termos mais usuais, uma caguetagem, revelando a existência de uma barreira cultural.

$\mathrm{Na}$ votação do Projeto de Lei n. 4.850/2016, referente às 10 medidas de combate à corrupção, na Câmara dos Deputados, o Deputado Edmilson Rodrigues (PSOL-PA), em seu pronunciamento, gravado no Diário da Câmara dos Deputados, ao tratar da proposta que instituía a figura do denunciante e dava-lhe incentivos financeiros nos casos de sucesso do relato, manifestou que "essa história de oficializar a deduragem remunerada é inadmissível”. ${ }^{168}$ A proposta acabou suprimida do texto com votação expressiva de 392 votos a 36, revelando a resistência dos parlamentares em relação ao tema.

A "boa” notícia é que, inclusive nos Estados Unidos, onde vimos que esse instrumento já alcançou um certo grau de consolidação na cultura social e política, o whistleblower passou por períodos de desconfiança, principalmente no início de sua institucionalização, quando recebeu o título pejorativo de Bounty Hunters (caçadores de recompensa). Em outros países, o reportante até pouco tempo conviveu com uma imagem negativa, como na Rússia e em algumas partes da ex-União Soviética, onde, embora tenha tido receptividade como ferramenta anticorrupção, ainda carrega, para muitos, uma conotação negativa de dedo-duro. Outras nações viram na definição dos termos/expressões uma forma de superar essa dificuldade cultural. Na Sérvia, por exemplo, a frase "conselho confidencial" pareceu mais aceitável do que "revelação" (disclosure). Na Holanda, preferiu-se utilizar uma designação para reportantes que remetia aos padres que, diante de um perigo iminente às cidades medievais, tocavam os sinos da igreja a fim de alertar a população, dando-lhes uma conotação positiva: os tocadores de sino (bell-ringers ou klokkenluider). ${ }^{169}$ Este trabalho terminológico demonstra a importância da cultura no processo de internalização do whistleblowing. Nesse sentido, precisamos evoluir bastante.

168 Diário da Câmara dos Deputados, ano LXXI, n. 208, novembro de 2016, p. 124.

169 Outras expressões distintas servem para designar os reportantes ao redor do mundo: "Lançadores de alerta" (Lanceur d'alerte), na França; "faroleiro" ou Lighthouse Keeper (közérdek bejelentés), na Hungria; "Gaiteiro" (Vilepuhuja), na Estônia. Transparência Internacional (2013). Whistleblowing in Europe: legal protections for whistleblowers in the EU, p. 20-21. 
Sem uma transformação cultural, na qual os empregados sejam encorajados a apresentar suas preocupações sem temer as consequências, é possível crer que uma reforma nesse sentido jamais terá plena eficácia, servindo apenas para compor o extenso rol de leis que "não pegam". As organizações públicas e privadas brasileiras ainda têm uma forte percepção de que a exposição de problemas internos relacionados à corrupção constitui um ato reprovável de deslealdade ao grupo, e não uma oportunidade ímpar de conhecer as deficiências e mapear as engrenagens frouxas, aprender com os erros, a fim de corrigi-los antes que se convertam em crises de gestão.

Nos países desenvolvidos, a revelação de informações de interesse público nas organizações acontece num ambiente de maturidade social avançada, que reconhece nessa prática a manifestação de um direito fundamental que deve ser protegido, uma ação social em prol da integridade. Em tais entidades, os problemas tendem a ser descortinados mais cedo, impedindo a ocorrência do prejuízo ou o seu agravamento.

Não é bastante, portanto, o suporte legal ou estritamente jurídico à consolidação do whistleblowing no cotidiano brasileiro, devendo também ser legítimo do ponto de vista social, isto é, de como as pessoas percebem - positiva ou negativamente - este instrumento e o quão eficiente ele pode ser na luta contra a gestão ineficiente e fraudulenta. Pergunta-se: quais são os possíveis elementos legitimadores? Em outros termos, que fatores poderiam contribuir para o desenvolvimento de um ambiente positivo em relação aos reportantes? As circunstâncias e características específicas de cada país impedem que eu forneça uma resposta exata a essas perguntas, porém, tendo em conta as experiências estrangeiras, é possível oferecer algumas linhas-básicas que foram induvidosamente cruciais neste desenvolvimento.

Primeiro: quanto maior o nível instrução e profissionalismo, especialmente no setor público, maior a probabilidade de que, diante de um dilema moral onde o sujeito tenha de decidir entre a obediência à hierarquia burocrática, lealdade à organização e os princípios éticos-profissionais que norteiam a sua carreira, decida pelo segundo, ainda que essa escolha implique assumir uma posição extremamente vulnerável, já que em entidades caracterizadas pelo rigor hierárquico há uma tendência em definir o dissenso como insubordinação. Roberta Ann Jhonson, da Universidade de São Francisco (EUA), argumenta que o aumento educacional e o treinamento profissional dos servidores públicos estimulam o whistleblowing, principalmente porque os funcionários podem sentir-se obrigados a seguir o seu código profissional de ética. A maioria dos episódios de resistência ética envolve aqueles que levaram realmente a sério as ideologias de sua profissão. Eles desenvolveram 
um comprometimento forte em manter os valores profissionais que enfatizam o significado de tomar decisóes com base em sua expertise e na responsabilidade ética individual. ${ }^{170}$ É especialmente importante, nesse contexto, que os indivíduos que confrontem a burocracia corrupta recebam o suporte das associações profissionais que integram, suprindo o isolamento que geralmente resulta da denunciação. Essa, todavia, é mais um impasse a ser superado no contexto de forte corporativismo presente no Brasil, uma vez que as associações profissionais e sindicatos geralmente têm ligação próxima e interesses mútuos com o governo, dificultando uma atuação autônoma em favor do empregado dissidente.

A experiência do engenheiro Demetrios Baskedas revela com precisão essa colisão entre a burocracia e a integridade profissional. Graduado e mestre em Engenharia Elétrica pela Universidade do Texas, com especialização profissional em engenharia nuclear, foi rapidamente indicado para ocupar um cargo na Divisão de Segurança dos Sistemas, da Comissão Regulatória Nuclear do governo federal norte-americano, passando a emitir licenças e autorizar a construção de reatores nucleares. Para ele, era a realização de um sonho funcional, produto do esforço e estudo de muitos anos. Após alguns meses no posto, descobriu que autoridades falsificavam dados técnicos a fim de obter continuação para as licenças de construção das plantas nucleares, comprometendo a segurança desses empreendimentos. Após ver as suas preocupações completamente ignoradas por seus superiores, Demetrios se viu diante do dilema moral que acomete quase todos os reportantes, o qual descreveu da seguinte forma: "É como se houvesse uma rodovia e você tivesse de escolher entre direita e esquerda. Você sabe que não conseguirá viver consigo mesmo caso escolha uma das direções [obediência à ilegalidade burocrática], mas sabe que se você escolher a outra rota, será extremamente difícil [agarrar-se aos princípios profissionais]". ${ }^{111}$ Escolheu o segundo caminho, e levou o caso ao Congresso Americano, que investigou os responsáveis e fez várias determinações à Comissão Regulatória Nuclear para que adequasse os seus procedimentos de concessão e licença.

Segundo: a mídia pode exercer uma influência significativa, caso dê destaque positivo àqueles que reportam atos de desconformidade. Não raro os reportantes se dirigem a agentes externos à organização para que sua denúncia tenha algum impacto, já que os canais internos estão obstruídos ou simplesmente não existem, tornando recorrente o socorro à imprensa como meio de revelação. Uma cobertura

170 JHONSON, Roberta Ann. Whistleblowing: when it works - and why? Lynne Rienner Publishers, 2003.

171 GLAZER, Myron Peretz; GLAZER, Penina Midgal. The whistleblowers: exposing corruption in government $\&$ industry. 
apoiadora é essencial para afastar a percepção social de que o whistleblower constitua uma espécie de traidor ou desleal. Jeffrey Wigand, a quem já nos referimos anteriormente, que denunciou em 1994 desvios no âmbito da indústria do tabaco norte-americana, após sucessivas tentativas frustradas de mudar internamente a política de composição dos cigarros, que continha elementos cancerígenos, somente conseguiu afetar a política e evitar danos maiores após uma entrevista ao programa 60 minutes, da rede de televisão CBS, uma das atrações de maior audiência dos Estados Unidos na época. O programa deixou uma impressão extremamente benéfica de Wigand, como alguém que salvou o interesse coletivo. A gravação de um filme contando a sua história (O Informante, 1999), contracenado por Al Pacino e Russel Crowe, ajudou a compor a imagem heroica desse reportante.

Terceiro: o efeito natural resultante da exposição de problemas internos de uma organização é o ostracismo. Raramente o reportante poderá contar com o suporte dos colegas de trabalho, menos ainda de seus superiores, que geralmente são os próprios responsáveis pelas irregularidades em curso. O cenário mais provável é a discriminação injustificada. A criação de organizações de interesse público da sociedade civil é essencial para afastar essa sensação de isolamento e empoderar o reportante, dando-lhe apoio psicológico, material e jurídico. Mas a importância dessas organizações não se esgota no apoio individual, mas na própria disseminação do ato de reportar como exercício de um direito cidadão inerente ao controle social, ajudando na difusão e desenvolvimento cultural do whistleblowing.

Tenho que estes três passos são fundamentais na tarefa de legitimação do $r e-$ portante. É óbvio que o contexto brasileiro pode trazer dificuldades adicionais que não foram pensadas em outros cenários, mas isso certamente não interferirá no processo como um todo.

Há, no entanto, um fator cultural-social que prepondera sobre os demais: a passividade-cidadã. Esse elemento tem se revelado especialmente forte no Brasil, onde a exposição cada vez mais frequente de escândalos públicos, da insuficiência ou incompetência do controle e da má-fé política produziu um sentimento geral de descrença e ceticismo. Evidência que não pode ser ignorada é que a tolerância à corrupção é maior onde é mais forte esta descrença democrática. ${ }^{172}$ Em meio ao

172 Conforme afirma o Latinobarômetro, de 2016: "dos dados presentes neste informe é possível concluir que naqueles países onde as pessoas percebem que avança a luta contra a corrupção, existe uma melhor apreciação da democracia, em comparação com aqueles onde se percebe o contrário. A corrupção constitui um indicador muito importante para conhecer à valorização da democracia" (tradução nossa). Dentre os países latino-americanos, o Brasil tem o segundo menor índice de "apoio à democracia", de acordo com o LatinoBarômetro de 2016, com 32\%, 
bombardeio jornalístico de episódios de propina, malas e apartamentos carregados de dinheiro público, captura dos órgãos de controle, o cidadão começa a aceitar o inaceitável, e confundir a recorrência da corrupção com a sua normalidade, calando-se frente às piores demonstraçōes de desprezo pelo patrimônio público. Não me deixa mentir a poesia de Rui Barbosa que, embora escrita há mais de cem anos, atualiza-se sem mudar:

Tenho vergonha de mim
pela passividade em ouvir,
sem despejar meu verbo, (...)
a tanta falta de humildade
para reconhecer um erro cometido,
a tantos "floreios" para justificar
atos criminosos,
a tanta relutância
em esquecer a antiga posição
de sempre "contestar"
voltar atrás
e mudar o futuro.

Em uma conjuntura tal de desalento, torna-se significativamente mais difícil que, diante de comportamentos imorais, o cidadão não vire as costas e permaneça calado, como um espectador apático do desastre.

$\mathrm{O}$ fenômeno da apatia do espectador (bystander effect) designa justamente aqueles indivíduos que, diante do mal iminente, preferem se abster a tomar uma atitude resolutória. A origem do termo é no mínimo chocante, e popularizou-se em 1964, a partir do caso do assassinato da jovem Kitty Genovese, em Nova York. Kitty foi assassinada na porta de sua casa, situada no bairro do Queens, sendo que as agressões que resultaram no óbito se arrastaram por certa de uma hora e meia. Não obstante seus gritos neste longo intervalo tenham sido ouvidos por 38 vizinhos, que assistiram à cena de suas janelas, nada foi feito para interromper a ação do criminoso. Esse episódio extremo e perturbador despertou o interesse de pesquisadores em entender as razões porque pessoas comuns podem tolerar condutas que de outro modo seriam ultrajantes.

somente à frente da Guatemala, com 31\%. No geral, a América Latina teve uma redução significativa no que tange à apreciação democrática, justificada por fatores políticos, a exemplo da corrupção e da crise de legitimidade. LatinoBarómetro (2016). Corporación LatinoBarómetro, Santiago, Chile, p. 8. 
Isso é válido não apenas para atrocidades como a ocorrida no caso Genovese, mas igualmente para pessoas que cometem um tipo mais comum de inércia - consistente em omitir-se quando uma atitude moral é exigida. Grande parte das fraudes e malversaçôes acontece com o conhecimento de agentes de dentro da organização. Quando eles presenciam esses atos e deixam de agir, estão dando aprovação tácita à continuação das atitudes antiéticas, além de incentivarem comportamentos semelhantes a partir de uma noção precária de normalidade. Passam a integrar a maioria silenciosa que torna a corrupção mais aceitável, tolerável e normalizada. Hannah Arendt tem a expressão correta: a banalidade do mal.

O que motiva esse silêncio? Por que aquiescer é o caminho mais escolhido?

Pode parecer que tomar uma ação contra a injustiça seja algo súbito e impulsivo, decidido em questão de segundos, mas o caminho que vai da aquiescência ao dissenso é longo e em seu intervalo encontram-se diversas inquietações, de modo que a apatia pode decorrer de vários motivos. Em geral, afirma-se que o silêncio é motivado por uma espécie de difusão da responsabilidade: quando diferentes pessoas presenciam uma ilegalidade e todas assumem que outro alguém benevolente e impetuoso, geralmente o Estado, irá se apresentar para resolver aquela situação. ${ }^{173}$ Ou seja: testemunhamos um problema, consideramos algum tipo de ação positiva que poderíamos tomar, e então respondemos fazendo... nada. É exatamente nesse sentido o alerta que fez Artur Dale Console, outro whistleblower norte-americano: "Não podemos cometer erro maior do que envolver-se em um senso de falsa segurança de que alguma força imaterial chamada governo irá atuar como um grande-irmão beneficente e tornar certo que interesses especiais não irão prevalecer. Se o interesse público tem de ser protegido, será somente pela ação das pessoas". ${ }^{174}$ Uma dependência muito grande do Estado pode aprofundar essa tendência à difusão, de modo a converter o governo em responsável universal pelos problemas da sociedade. $\mathrm{O}$ forte oficialismo que ainda prevalece em território brasileiro tende a agravar essa questão.

A sensação de conformidade originada da tolerância crescente às práticas irregulares também constitui um elemento importante de refreamento e passividade. $\mathrm{Na}$ medida em que as pessoas ao redor apresentam despreocupação, a hesitação se

173 KELTNER, Dacher; MARSH, Jason. We Are all bystanders. Bekerley University, Greater Good. Disponível em: <http://greatergood.berkeley.edu/article/item/we_are_all_bystanders/>. Acesso em: 29 maio 2017.

174 GLAZER, Myron Peretz; GLAZER, Penina Midgal. The whistleblowers: exposing corruption in government $\&$ industry, p. 44. 
torna mais provável. Já tive a oportunidade de discutir os efeitos negativos dessa conformidade social para a percepção da sociedade frente à corrupção e a eficácia do controle social em outra obra (O Ovo da Serpente, 2016), mas a perspectiva de análise em relação à iniciativa para reportar atos corruptos é bastante semelhante. $O$ processo de normalização da imoralidade tem um efeito multiplicador nas pessoas, que passam a reagir (ou não reagir) conforme outras a sua volta. Se a percepção geral é de que a ineficiência, o desperdício e a fraude não importam tanto, a indignação a ponto de criar uma resistência ética torna-se mais difícil.

Embora detenham aspectos mais psicológicos do que propriamente culturais, pode-se apontar outros coeficientes potencialmente influenciadores dessa relação complexa: (i) a expectativa de resultados, quer dizer, mesmo quando existe o que parece ser um senso comum e claro sobre a ilicitude da situação, a maioria das pessoas não a revela em função do que elas acreditam que irá ou não acontecer como resultado. A antecipação negativa de consequências é, na realidade, um dos principais elementos bloqueadores da ação de reportantes; (ii) a inversão de valores, semelhante àquela retratada no diálogo que expus ao início, baseado na crença de que não há problemas em perseguir o sucesso pessoal e se limitar a fazer o seu, enquanto a injustiça prevalece no entorno.

Todas essas variantes compõem e interferem no dilema ético invocado por qualquer sujeito que se depare com uma situação irregular e tenha de agir para corrigi-la. Como fazer com que as pessoas resolvam este teste-moral de modo a gerar ações virtuosas ao invés permanecer em silêncio não é algo que eu possa responder com um grau de certeza razoável, dadas as particularidades das situações e características inerentes a cada indivíduo. Nem a Psicologia ou a Neurociência conseguiram chegar a um consenso. No entanto, uma ideia preliminar é possível e pode ajudar a construir uma resposta segura: os valores culturais, principalmente os relacionados à educação ética e ao espírito cívico da sociedade.

Em situações nas quais se está diante de um problema sério que afeta gravemente o interesse público, pode não haver desconforto para os agentes que praticam a gestão fraudulenta, corrupta e inescrupulosa, já acostumados a conviver com a impunidade, mas certamente faz surgir um incômodo moral àqueles que presenciam esses atos. Incômodo que é tanto mais agudo quanto mais apego tem a pessoa aos princípios éticos que fizeram parte de sua vida. Tendo esse civismo sólido e estabelecido, a corrupção nos parecerá cada vez menos justificável, e o que hoje vemos de forma deturpada como normal, será motivo para a mais forte indignação. É um cenário ideal. Seria no mínimo ingênua caso afirmasse que esse estado de coisas esteja próximo, ou que possa ser atingido com algumas reformas aqui e acolá. 
A transformação ético-cultural é uma caminhada dura e intergeracional, da qual provavelmente não desfrutaremos, mas temos a chance de iniciar. Quer se queira ou não, reportar livremente envolve uma grande mudança na abertura e transparência. Assim, insistir na educação cívica primária tende a aprimorar aspectos importantes da resistência ética. Em primeiro lugar, ajuda a desenvolver a percepção de fatos que não estão corretos. Isso gera um constante questionamento e a busca permanente por informações que auxiliem na tomada de atitudes responsáveis, a fim de corrigir uma situação irregular. Incrementa também a resistência pessoal necessária para se manter firme aos princípios éticos que são ensinados e consolidados desde a primeira infância. Finalmente, reduz consideravelmente a tendência em racionalizar a inação e criar justificativas para tornar atos imorais em aceitáveis ou menos injustos. Em geral, não há nenhuma dúvida de que sem educação não há mudança substantiva da nossa realidade tão igual e tão suscetível ao corrompimento.

A barreira cultural existe, mas é possível superá-la e creio que já estamos começando a reduzir este muro, que não é de modo algum intransponível. Precisamos corrigir a miopia ética e entender que sinalizar discordância com uma situação que consideramos errada e marcar posição sobre o que reputamos intolerável pode e deve ser feito, muito mais como exercício de um direito, do que forma de deduragem remunerada.

\section{Desenvolvimento de uma política de Whistleblowing}

Ultrapassado esse aspecto cultural, inevitavelmente mais genérico e teórico, conforme lhes antecipei, posso agora discutir medidas práticas e concretas para a construção e institucionalização de uma política de whistleblowing. Nesse ponto, não estarei limitada à mera observação, de modo que espero contribuir de alguma forma para a consolidação dessa forma de exercício eficaz do controle social no Brasil. A intenção é instigar estudos futuros sobre o tema, subsidiar propostas legislativas e programas de integridade ou, que seja, abrir a cabeça do leitor para a possibilidade de exigir das lideranças políticas ou da organização onde trabalha reformas nesse sentido.

Além disso, expondo os critérios para o desenvolvimento de uma política efetiva de denúncia, desejo evitar que se produzam esforços legislativos incompletos ou fragmentários, que trarão mais riscos do que segurança aos cidadãos, gerando poucos resultados. Considerando que o medo de represálias e a falta de proteção é uma das principais razões pelas quais indivíduos decidem não reportar os atos 
ilegais de que têm conhecimento, ${ }^{175}$ é importante elaborar um programa completo, ${ }^{176}$ sem lacunas que possam representar uma armadilha ao cidadão reportante. Conforme preceituado na Resolução n. 1.729/2010, do Conselho Europeu (item 5), ${ }^{177}$ reportar sempre requer coragem e determinação e aos reportantes deve ser dada pelo menos a chance de lutar para que seus alertas sejam ouvidos, sem que precise arriscar suas vidas e a de seus familiares. Uma legislação relevante deve primeiro e principalmente promover uma segurança alternativa de silêncio e não oferecer aos potenciais reportantes um mero escudo de papel que dê falsa sensação de segurança. Nesse sentido, um programa de relatos confiável deverá fornecer diferentes instrumentos que deem segurança ao empregado de que eventuais represálias serão coibidas e devidamente responsabilizadas. A construção adequada dessa via que liga o cidadão ao controle é vital nos esforços para prevenir abusos.

Por outro lado, é relevante prover incentivos e estímulos para a participação da sociedade no oferecimento de informaçôes em defesa do interesse público. Outros mecanismos servirão a essa finalidade (recompensa financeira, comunicação, não punição de denúncias infrutíferas), e deverão compor igualmente o programa de whistleblowing.

Dada a insuficiência de norma nacional específica, as propostas aqui delineadas fundamentam-se majoritariamente nas indicações e linhas-básicas formuladas pelas organizações e documentos internacionais anticorrupção, e que serviram de referência no desenho e implementação dos canais de relatos em outros países, tais como: "Politicas Governamentais de Whistleblowing" e "Fazendo a Politica de Relatos Funcionar", elaborados pelo órgão de Auditoria Nacional do Reino Unido (NAO), com base em 39 legislações estrangeiras, além das recomendações da Transparência Internacional, OCDE, o Modelo Legal de implementação da Convenção Interamericana Contra a Corrupção (2013) e o "Guia de Boas Práticas na Proteção de Pessoas Reportantes" (2015), da Convenção das Nações Unidas contra a Corrupção.

175 De acordo com pesquisa realizada nos países do continente europeu, as principais razões que ensejam o silêncio dos potenciais reportantes são: (i) a dificuldade em provar o caso; (ii) a presunção de inutilidade da denúncia, já que não haveria punição dos responsáveis ao final do processo; (iii) o medo de represálias e a falta de proteção suficiente. The European Comissions Special Eurobarometer 397: Corruption (Bruxelas: Comissão Europeia, 2014).

176 Daqui em diante, o termo "programa" será utilizado de forma genérica para designar uma política dedicada aos relatos de corrupção, ou um Programa Especial de Reportantes, relacionado às medidas e ações destinadas a proteger e incentivar a revelação de informações de interesse público.

177 Conselho Europeu. Resolução n. 1.729 (2010), Final version protection of whistleblowers Parlamentary Assembly, item 5. Disponível em: <http://assembly.coe.int/nw/xml/XRef/Xref-XML2HTML-en.asp?fileid=17851\& lang=en>. Acesso em: 24 maio 2017. 
- Finanças públicas: travessia entre o passado e o futuro

A condição básica e primária para o funcionamento do programa é que os procedimentos adotados sejam claros e abertos. Muitas pessoas tomam conhecimento ou vivenciam uma situação de corrupção, mas são inibidos de soar o alerta não por ausência de vontade ou espírito cívico, mas simplesmente por desconhecer os meios protetivos que estão à sua disposição. ${ }^{178}$ Eliminando o elemento incerteza deste processo, mais pessoas virão à tona com as ilegalidades que porventura detectarem.

Alguns aspectos que já foram abordados quando conceituamos o whistleblowing, no começo deste capítulo, devem ser incluídos e delineados no âmbito do programa especial. Assim, é bom que a definição dos relatos eventualmente protegidos seja compreensiva e ampla, de maneira a abranger denúncias de boa-fé que digam respeito a tipos variados de irregularidade, que não estejam restritos à corrupção conforme tipificada no código criminal. Ideal que se inclua, neste parâmetro, quaisquer atos graves que atentem contra os princípios da administração pública, patrimônio coletivo, probidade administrativa, direitos e garantias fundamentais, ordem econômica, tributária, meio-ambiente, saúde pública, relação de consumo e livre concorrência. ${ }^{179}$ A Convenção das Nações Unidas contra a Corrupção ressalta que a identificação ampla das más-práticas abarcadas pela norma facilita o entendimento e, por consequência, a realização da denúncia. Porém, alerta que a utilização exclusiva de critérios genéricos como interesse público ou bem-estar pode dificultar a compreensão, de modo que faz sentido prever expressamente os tipos exemplificativos de más-condutas que integram o escopo da legislação. ${ }^{180}$ Além disso, o programa deve fornecer proteção eficaz a reportantes que provenham tanto do setor público, como do setor privado, sem

178 Eurobarometer: Se vivenciasse ou testemunhasse um caso de corrupção, saberia onde denunciar? 44\% disseram que não - na Europa, onde já há uma legislação basicamente consolidada de whistleblowing. Transparency International (2015). Mariya Gorbanova. Speak Up: Empowering citizens against corruption.

179 Explanatory memorandum to the Council of Europe Recommendation on the protection of whistleblowers(2014),p.43.Disponívelem:<https://wcd.coe.int $/$ ViewDoc.jsp?id=2170183\&Site=CM>. Acesso em: 25 maio 2017.

180 O Guia de boas práticas da Convenção das Nações Unidas cita a Lei de Proteção aos Whistleblowers da Malásia, que não se vale dos termos "interesse público" ou "más-condutas", mas refere-se a um espectro amplo de informações que podem ser consideradas "revelações a serem protegidas" pela norma. Refere-se a conduta imprópria como "qualquer conduta que se comprove constituir uma ofensa disciplinar ou criminal", e define ofensa disciplinar como "qualquer ação ou omissão que constitua falha de disciplina no setor público ou privado, na forma da lei, do código de conduta ou do código de ética ou, ainda, do contrato de trabalho, de acordo com as circunstâncias do caso" (UNCAC, p. 23). 
prejuízo dos canais internos que devam ser instalados nas organizações para apreciação desses relatos.

No tocante ao relato em si, conforme já afirmamos, é essencial definir de forma mais objetiva possível quais os critérios para verificar a razoabilidade ou a boa-fé da denúncia, a exemplo do que propõe a OCDE, no Plano de Proteção aos Reportante aos países do G-20, ao entender como razoável a conclusão que um observador desinteressado retiraria dos mesmos fatos. ${ }^{181}$ Nessas circunstâncias, ainda que alguém se engane quanto ao significado das informações fornecidas e nenhuma impropriedade seja detectada, permaneceria protegido pelo fato de ter relatado. Com isso, evita-se que a avaliação da boa-fé se converta no exame dos motivos pessoais do reportante, retirando o foco do que realmente importa: as informações sobre corrupção. Outrossim, o projeto deve expor os elementos indicativos de relevância que serão utilizados como parâmetro para rejeitar relatos de ocorrências consideradas de menor expressão, bem como quais serão os elementos que deverão compor o relato (documentos). O objetivo é reduzir a subjetividade na hora da decisão que recebe ou não a denúncia, impedindo que eventual ingerência política ou hierárquica interfira no juízo.

Afora tais pontos materiais importantes, o programa deve conter, pelo menos, três bases necessárias para facilitar os relatos e proteger os reportantes: canais institucionalizados, proteção antirretaliação e confidencialidade, além de um elemento complementar que, embora não seja necessário, é apontado como relevante à efetividade do programa: o sistema de recompensas.

\section{A) A institucionalização de canais}

Os indivíduos que desejam reportar situações ilícitas, ineficientes ou perigosas precisam dos meios apropriados para compartilhar suas preocupações. Para isso, é necessário estabelecer canais institucionalizados responsáveis pelo recebimento dos relatos, investigação dos fatos narrados e garantia da segurança do reportante.

Não há um padrão estabelecido ou modelo universal na projeção destes canais. Para implementá-los, é preciso levar em conta, primeiro, a variedade de cenários que podem surgir a partir do desenho do programa. Se uma pessoa reporta internamente o problema ao seu supervisor e acaba sofrendo represálias, estará ele ou ela protegido(a) pela legislação? Como essa situação difere de quando a pessoa

181 G20 Anti-corruption Action Plan PROTECTION OF WHISTLEBLOWERS, p. 8. Disponível em: <http://www.oecd.org/g20/topics/anti-corruption/48972967.pdf>. 
relata comportamentos inapropriados a um órgão ou autoridade competente externa, como uma agência anticorrupção ou um órgão de controle específico encarregado de lidar com as denúncias? Ainda, sob que circunstâncias poderia a proteção incidir se a pessoa revelar as informações por vias mais amplas, como a imprensa ou pela internet? Estas questôes são cruciais e as respostas servem tanto aos funcionários do setor público quanto privado.

A Irlanda e o Reino Unido desenvolveram uma abordagem ampla cuja análise pode nos ser proveitosa. Adotou-se nestes países uma institucionalização em três níveis, a fim de proteger os reportantes no setor público e privado: o primeiro nível diz respeito ao relato interno, feito ao superior (empregador) ou outra pessoa autorizada pela própria organização; o segundo nível refere-se ao relato dirigido a uma autoridade competente externa ou para algum Ministro (Comissionário); o terceiro nível consiste em revelações através de vias mais difusas, como a imprensa ou internet. Embora a norma tenha uma predileção aos relatos internos, haja vista permitir uma análise mais próxima e inicial do problema, o denunciante pode levar as informações diretamente à autoridade externa ou até mesmo, de forma excepcional, à mídia, e mesmo assim receber a proteção legal ou, eventualmente, a compensação financeira.

Um regime institucionalizado de proteção aos relatos é particularmente relevante, pois dá alternativas claras ao reportante, aumentando a sensação de segurança. ${ }^{182}$ Para mais, a inexistência de canais internos ou o seu funcionamento inadequado não devem obstruir a proteção das denúncias realizadas por outras vias.

O desafio principal é estabelecer processos e regras claras a fim de prover essas alternativas e levá-las ao conhecimento dos potenciais reportantes, tornando mais seguro denunciar. Para tanto, será necessário que o procedimento adotado por estes canais e a tramitação posterior dos relatos estejam definidos de antemão, com a identificação dos agentes que trabalharão em cada etapa, da recepção, investigação, à tomada de decisão. A desconfiança quanto ao cenário pós-denúncia é um fator decisivo para quem decide denunciar. ${ }^{183}$

182 A Lei de Proteção às Revelações de Interesse Público da Austrália (2013) utiliza outra ramificação interessante, baseada na natureza do relato. Apresenta relatos internos, no primeiro nível, feitos a um "recipiente interno autorizado" ou supervisor; relatos externos, feitos a qualquer pessoa que não um agente público; relatos emergenciais, que trata de danos iminentes e, por último, a revelação legal, que ocorre diretamente no âmbito Judiciário. (Public Interest Disclosoure Act 2013, Subdivision A; 26).

183 O Public Concern at Work, organização de interesse público do Reino Unido que auxilia whistleblowers, através de pesquisa realizada em 2015, descobriu que existe um vácuo crítico entre 


\section{a.1. Canais internos}

Não obstante a existência de organismos estatais de controle da corrupção, constata-se que a grande maioria dos empregados prefere soar o primeiro alerta em seu local de trabalho, para um supervisor, chefe de departamento, ou alguém responsável pela investigação interna do problema. ${ }^{184} \mathrm{O}$ relato para fora da organização geralmente é produto de um longo e sinuoso processo de frustrações e negações dentro da organização.

Alguns países determinam em lei a criação desses canais internos, enquanto outros deixam a decisão quando à sua implementação nas mãos das organizações, estabelecendo apenas estímulos legais. No Brasil, inobstante a falta de regulamentação específica, há um fator positivado de incentivo à estruturação dos canais internos no âmbito dos programas de conformidade (compliance). É que o art. 7on, VIII, da Lei Anticorrupção prevê que será levado em consideração, na aplicação das sançôes administrativas de que trata a lei, dentro outros elementos, a existência de mecanismos e procedimentos internos de integridade, incluindo o incentivo à denúncia de irregularidades. A possibilidade de reduzir eventual punição tem levado as empresas brasileiras a construir canais internos, embora não haja evidências acerca do real funcionamento ou efetividade deles, e se as denúncias recebidas são realmente levadas à sério. $\mathrm{O}$ fato é que a implementação adequada de um canal interno de denúncias demonstra, ao menos, que a organização se preocupa com a prevenção e detecção de ilícitos relacionados à corrupção.

Em todo caso, é fundamental que o mecanismo funcione, que os seus potenciais usuários possam confiar no sistema. Se o funcionário assume que sua denúncia não será levada a sério, e que nada mudará a partir do relato, certamente não irá se expor aos riscos que implica utilizar o canal. A seriedade e imparcialidade nos procedimentos e na política de denúncias seguramente ajudarão a conquistar essa confiança, desenvolvendo uma boa cultura coorporativa.

o número de vezes que uma pessoa reporta um problema antes que ela desista (uma ou duas vezes), e o número de vezes que uma organização recebe uma denúncia antes de agir (três a quatro vezes). Public Concern at Work (PCaW), Whistleblowing: time for change (2015).

184 De acordo com uma pesquisa realizada em 2013 pela organização de interesse público do Reino Unido, Public Concern at Work, em conjunto à Universidade de Greenwich em 1.000 casos de whistleblowing, em $82 \%$ dos casos, indivíduos levantaram suas preocupações, primeiro, aos seus empregadores. Public Concern at Work and University of Greenwich, (2013). Whistleblowing: the inside story. A study of the experiences of 1,000 whistleblowers. London. Disponível em: <http://www.pcaw.org.uk/whistleblowing-theinside-story>. Acesso em: 20 maio 2017. 
No setor privado, os canais internos permitem conhecer os fatores de risco que ensejam oportunidades para a corrupção, possibilitando uma atuação consciente, tempestiva e eficaz na correção destas áreas de fragilidade e aprimoramento do controle. Para a empresa, a via interna de denúncias dos funcionários e terceiros relacionados funciona basicamente como um zelador de reputaçōes, pois evita que problemas incipientes tomem proporções incontornáveis e prejudiciais, ou que o reportante procure formas mais difusas de publicitar as condutas imorais que estejam ocorrendo. O pronunciamento de Bob Ansell, diretor de controle interno da Philip Morris Limited, sintetiza bem o que deveria ser esse natural interesse do setor privado pela implementação do whistleblowing dentro dos programas de integridade: "Preferirei muito mais que o indivíduo fale para mim do que para um jornal ou programa de televisão". 185

De qualquer forma, o responsável por lidar com as denúncias recebidas no âmbito da companhia (através do setor de compliance, ou outro departamento), deve dispor de estabilidade e independência funcional que garantia sua autonomia. Questão que merece análise concerne à proteção do empregado que realiza uma denúncia internamente e seja vítima de retaliação. Caso a lei não traga salvaguardas, o reportante acabará numa encruzilhada e provavelmente terá que recorrer à justiça para provar o seu caso, o que, sabemos, é extremamente complicado. É importante, desta forma, que a legislação antecipe mecanismos de proteção para situaçóes dessa natureza, bem como caminhos alternativos para o funcionário que queira revelar informaçōes graves, como faz o Reino Unido. Outro aspecto relevante é que o empregado saiba para onde direcionar suas alegaçôes, assim como as providências que serão tomadas por quem caiba recebê-las, de maneira que essas informaçóes lhe sejam comunicadas durante todo o trâmite interno na companhia.

No setor público, o estímulo aos relatos internos e a formação de sistemas próprios para o recebimento de denúncias dos servidores integram uma noção transparente e aberta de gestão e boa-governança. Particularmente no ambiente estatal, onde a sociedade exige cada vez mais o seu quinhão de participação e um incremento em termos de decência na gestão da coisa pública, o reportante desempenhará um papel primoroso de fiscalização preventiva por dentro. Esta seara já é ocupada de certa forma pelas ouvidorias nos órgãos públicos, embora o escopo não seja exatamente o mesmo, vez que tal sistema não confere proteção ou recompensa ao denunciante e, geralmente, se limita ao recebimento de denúncias anônimas.

185 WOLFE, Simon et al. Whistleblower protection laws in G20 countries: priorities for action. Setembro 2014, p. 20. 
Assim, é impostergável que a legislação de cada ente político preveja a criação de canais específicos de proteção e incentivo no âmbito dos organismos estatais. A Lei sobre Revelações de Interesse Público da Austrália (2013), ${ }^{186}$ aplicável aos servidores públicos em geral, determina que os órgãos públicos criem, no âmbito de suas estruturas, um recipiente interno autorizado (authorised internal recipient) para o recebimento de relatos de interesse coletivo, e promoção das ferramentas de proteção. Há uma proposta semelhante no Brasil, levantada pelo ENCCLA (Estratégia Nacional de Combate à Corrupção e Lavagem de Dinheiro), que sugere a instalação, preferencialmente na estrutura das unidades de ouvidoria dos órgãos e entidades públicas, das chamadas Comissóes Permanentes de Recebimento de Relatos, para receber relatos de informações de interesse público e promover a investigação dos fatos narrados. ${ }^{187}$

Enfim, embora desejável, denunciar internamente um problema afeito à corrupção pode não ser um caminho fácil ou satisfatório, a julgar pela alta probabilidade de que as informações sejam menosprezadas, ou que os responsáveis sejam acobertados. Nesse caso, um programa de proteção aos reportantes de boa-fé deveria se preocupar em criar uma agência estatal específica ou encarregar entidades já existentes para receber e tratar as denúncias, garantindo que serão apurados os fatos, oferecida a proteção ao reportante e eventualmente conferida uma recompensa.

\section{a.2) Canais externos}

É fundamental que o reportante possa contar com opções externas à organização, paras as quais consiga expor suas preocupações e requerer proteção contra retaliações injustas. As autoridades ou instituições externas geralmente têm um papel que extrapola a relação de trabalho, possibilitando mais segurança ao reportante,

${ }^{186}$ Lei sobre Revelações de Interesse Público, 2013, Subdivisão C - Revelações Internas: recipientes internos autorizados, 34 .

187 A proposta ENCCLA, a propósito, serviu de base para o substitutivo ao PL n. 4.850/2016, aprovado na Comissão Especial da Câmara dos Deputados. A proposta de criação da Comissão de Recebimento de Relatos (CRR) recebeu críticas da Associação dos Delegados da Policial Federal (ADPF), por implicar a fundação de uma nova estrutura organizacional na administração pública brasileira, que mais se assemelharia a uma "polícia secreta", já que deteria poderes de investigação e concessão de medidas protetivas, sugerindo, em contrapartida, que os fatos que configuram crimes seja imediatamente comunicados, pela CRR, à autoridade de polícia judiciária para instauração do inquérito policial (Of. n. 215/2016-ADPF. Assunto: PL. 4.850/2016 - Nota técnica da ADPF). 
além de possuírem uma experiência profissional que garante orientação eficaz e autônoma aos relatos. A implementação dos programas de whistleblowing devem levar em conta tal aspecto e definir acerca da existência destas autoridades ou órgãos exógenos.

Em termos comparativos, não há um modelo universal adotado pelos países na designação da autoridade estatal responsável pelas denúncias.

Há sistemas que preferem centralizar a atividade de recebimento e investigação dos relatos, através da criação de instituições específicas de prevenção, conscientização e combate à corrupção, conhecidas internacionalmente pela sigla ACA (Anticorruption Agencies) como ocorre na República da Coreia do Sul, onde a Comissão Anticorrupção e de Direitos Civis, criada em 2008, recebe as denúncias relacionadas à corrupção ou informações referentes a fraudes, desperdícios ou abusos, podendo conceder recompensas financeiras pelo relato. Esta comissão, contudo, não investiga os casos por si própria, mas delega referida competência a outros órgãos, monitorando a apuração e fixando limites temporais de apuração. ${ }^{188} \mathrm{O}$ Brasil não possui uma agência pública anticorrupção centralizada de natureza semelhante à Comissão Anticorrupção e de Direitos Civis. Ao invés disso, detemos uma estrutura complexa (e confusa) de órgãos que se sobrepõem no controle da corrupção. Coordenar os esforços através da criação de uma instituição específica de conscientização, prevenção e combate à corrupção, que dentre outras atribuições recebesse denúncias de servidores e empregados, é uma ideia que não pode ser descartada. Aliás, a institucionalização das agências anticorrupção é recomendada pelas organizações internacionais e tem sido adotada em países desenvolvidos, a exemplo da França, que inaugurou em 2017 a Agência Francesa de Luta Anticorrupção (Agence Française de lutte anticorruption).

Ainda quanto à estruturação centralizadora, a Convenção Interamericana contra a Corrupção recomenda que a autoridade competente para a apuração e proteção dos denunciantes deve ser um órgão responsável pela fiscalização administrativa do serviço público, preferencialmente no âmbito do Poder Executivo. ${ }^{189}$

Outros arranjos estendem a competência para o recebimento dos relatos a diversas entidades, como faz a Lei de Revelações de Interesse Público (PIDA), do

188 The United Nations Convention against corruption: resource guide on good practices in the protection of reporting persons. Nações Unidas, 2015, p. 37.

189 Convenção Interamericana contra a Corrupção. Modelo de Lei para facilitar e encorajar o relato de atos de corrupção e a proteção de whistleblowers, art. $3^{\circ}$ (2013). 
Reino Unido, que inclui uma lista de pessoas prescritas ou órgãos escolhidos pela Secretaria de Estado, para lidar com as informaçōes, a exemplo da Agência Nacional de Crimes, Ministério das Finanças e o conhecido Departamento de Fraudes Sérias (Serious Fraud Office).$^{190}$ Transportando a ideia para o Brasil, poder-se-ia destinar essa atribuição a órgãos como a Controladoria-Geral da União, Tribunal de Contas, CADE, entre outros.

Independente do modelo que venha a ser adotado, a autoridade competente deve pautar sua atuação pela imparcialidade, imune a influências políticas e econômicas, com poderes para investigar condutas irregulares, determinar medidas corretivas e de proteção necessárias à prevenção ou cessação de atos retaliatórios praticados contra o denunciante, cuja identidade deve ser resguardada, garantindo também que este conheça o resultado da apuração. Para mais, é aconselhável que os órgãos responsáveis promovam a publicação periódica dos resultados auferidos a partir dos relatos recebidos (número de denúncias recebidas e concluídas, valores restituídos, medidas protetivas aplicadas etc.).

No entanto, mesmo contando com a existência de estruturas internas e externas, é possível que o reportante necessite de outras vias de revelação. Caro leitor, imagine-se na seguinte situação: você ocupa um cargo na Secretaria de Educação de determinado Estado da federação. Certa feita, toma conhecimento de fraudes na aquisição de materiais escolares às escolas públicas da região, praticadas pelo próprio Secretário Estadual, em conluio com outros agentes e fornecedores. Munido de documentos que comprovariam estes atos de corrupção, e determinado a interromper essa violação do interesse público, você decide relatar a situação junto ao (hipotético) canal de denúncias do órgão. Por coincidência ou não, o responsável pelo recebimento dos relatos internos é primo do secretário e foi por ele indicado, e lhe informa que a denúncia fora arquivada devido à "falta de documentos que comprovem as alegações que constam na denúncia”. Além disso, a falta de compromisso e eficácia na proteção da identidade do reportante tornou possível à autoridade corrupta saber quem o denunciara. No dia seguinte, o Diário Oficial estampa a sua exoneração do cargo. Ainda convencido de que aquelas ilegalidades não poderiam prosseguir, você se dirige ao (também hipotético) Comitê de Proteção aos Relatos de Interesse Público, na Controladoria-Geral do Estado, órgão competente para receber e investigar relatos e proteger denunciantes. Comprometido com o governador do estado e, sabendo da repercussão negativa que aquelas alegaçôes poderiam acarretar à imagem do gestor, o diretor do Comitê simplesmente se

190 Public Interest Disclosure Act (1998), Chapter 23. 43 F, 43 G. 
omite e nenhuma medida efetiva é tomada. No final das contas, você perdeu a única fonte de renda para seu sustento e a denúncia morreu na placenta. Em situaçôes como essa, dentre as poucas alternativas que restam - a mais forte certamente é a desistência ou simples aceitação da prática corrupta - recorrer à imprensa parece ser a mais prudente.

$\mathrm{Na}$ prática, pode ser que apenas com a divulgação ampla, os atos corruptos sejam identificados e alguma atitude concreta para refreá-los seja levada a efeito. A propósito, Mirabete dizia que a essência da denúncia, como ação cívica, consiste em contar com os efeitos da publicidade sobre algo imoral, o que é reforçado por Bobbio, ao afirmar que o que difere o regime democrático do poder autoritário é precisamente a possibilidade que existe apenas no primeiro de desenvolver os próprios anticorpos e promover formas de desocultamento, dentre as quais a denúncia de escândalos. ${ }^{191}$ Particularmente quando as vias comuns estão obstruídas ou quando haja risco iminente à segurança da coletividade, a proteção a quem utilize de canais alternativos, como a imprensa ou a internet, deve ser considerada.

\section{B) Proteção antirretaliação}

A proteção do reportante contra retaliações é condição necessária para qualquer programa de relatos sobre corrupção. A lógica é simples: um trabalhador dificilmente decidirá expor informações de interesse público se não se lhe preservar das possíveis reaçóes injustas - de seus superiores ou de outros trabalhadores - que prejudiquem a sua carreira profissional ou integridade pessoal. Enquanto o agente imoral tiver condiçôes de impor medo, prevalecerá o silêncio dos inocentes sobre a coragem da dissidência. Desta forma, a configuração do sistema protetivo é determinante no sucesso do programa de whistleblowing.

Discriminação e punições contra os resistentes éticos não são casuais. ${ }^{192} \mathrm{Em}$ bora à primeira vista pareça tomar a forma de vingança pessoal por parte dos

191 BOBBIO, Norberto. O futuro da democracia. 6. ed. Rio de Janeiro: Paz e Terra, 1997, p. 102.

192 De acordo com pesquisa realizada em 2014, nos Estados Unidos, pelo Centro de Pesquisa sobre Negócios e Ética Corporativa, quando questionados sobre os motivos pelos quais mantiveram-se em silêncio a respeito de irregularidades, $34 \%$ daqueles que preferiram não reportar disseram que temeram revides por parte de seus superiores. $24 \%$ afirmaram que os companheiros de trabalho poderiam reagir contra eles. Além disso, entre aqueles que escolheram reportar, aqueles que sofreram retaliações no passado tenderam menos do que aqueles que não experimentaram represálias (minoria) a dizer que reportariam más práticas novamente se as vissem. Ethics Resource Center. National Business Ethics Survey: of the U.S Workforce, NBES 2013. 
denunciados, a retaliação se insere em um processo racional para destruir a credibilidade do dissidente como denunciante. O repertório de estratégias para alcançar este intuito é vasto: demissão arbitrária, remoção, assédio pessoal, alocação do empregado para funções de menor relevância na empresa, retirada de atribuiçõos como forma de marginalização, alegação de violação do sigilo institucional ou empresarial ou de rompimento das obrigaçōes de confidencialidade do contrato de trabalho, por divulgar informaçóes internas. $\mathrm{Na}$ maioria dos casos, intenta-se ignorar as alegações dos reportantes, sugerindo que são indivíduos emocionalmente desequilibrados ou moralmente suspeitos. ${ }^{193}$

Ao fazer isso, a organização pretende ainda enviar um sinal, uma forma de punição exemplar, para que outros funcionários se convençam que confrontar a autoridade implica em altos riscos e resultará em prejuízos concretos à carreira profissional.

Por isso, diferentes mecanismos de proteção devem ser considerados no propósito de inibir práticas de retaliação, que incidirão no âmbito trabalhista, processual e pessoal. No geral, as medidas protetivas devem ser desenhadas de modo a assegurar a integridade física e psicológica do reportante e de sua família, preservando suas condições de trabalho e o padrão de vida.

Contudo, como as condutas denunciadas acontecem principalmente no ambiente de trabalho, e a informação revelada pode prejudicar os interesses da organização afetada, é no cenário laboral que se dá a maior parte das represálias contra o dissidente. Portanto, nesta seara, poderia incidir medidas como: reintegração ao posto de trabalho, com direito à indenização e compensação pelos dias não trabalhados em virtude da demissão injusta; transferência de unidade administrativa dentro da agência; e inversão do ônus da prova em processos judiciais que discutam essa relação, fazendo com que o empregador tenha de comprovar a inexistência do nexo causal entre o ato de retaliação (demissão, remoção etc.) e a denúncia do funcionário. Tal inversão probatória talvez seja a ferramenta mais importante, dada a dificuldade usual do reportante em demonstrar que as represálias decorrem diretamente do fato de ter revelado condutas impróprias, atribuindo, portanto, à autoridade denunciada, o ônus de provar que o ato presumidamente injusto ocorreria de qualquer modo, independentemente da revelação das informações pelo funcionário. ${ }^{194}$

193 ALFORD, Fred C. Whistleblowers' Broken Lives and Organizational Power. Ithaca, NY: Cornell University Press, 2001.

194 Países que têm regulações neste sentido: Croácia, França, Luxemburgo, Nova Zelândia, Noruega, Eslovênia, África do Sul, Reino Unido e Estados Unidos, além de ser recomendado pelo 
Outras medidas importantes podem ser cogitadas: assistência jurídica para ações judiciais relacionadas à denúncia, imunidade civil e administrativa do reportante de boa-fé (waiver of liability); assistência médica e psicológica, além de proteções mais excepcionais como segurança policial ou mudança de residência, que embora estejam mais relacionadas a casos criminais envolvendo organizações criminosas, podem aplicar-se também a reportantes de atos de corrupção. ${ }^{195}$

Uma crítica justa direcionada à Lei de Revelação de Interesse Público (PIDA), de 1998, do Reino Unido, antes das reformas implementadas em 2013, é que referida lei somente conferia proteção aos reportantes depois da efetiva ocorrência de retaliações, o que geralmente mostrava-se inoportuno e intempestivo. Para evitar que isso aconteça, é conveniente estabelecer medidas preventivas que resguardem a integridade e os direitos do informante contra atos repreensivos, de modo que este não precise atravessar um caminho penoso antes que alguma atitude seja tomada.

Neste propósito de precaução, uma das providências mais relevantes é a preservação da identidade do reportante. Pela importância que tem a confidencialidade ao funcionamento do programa de relatos, devemos analisa-la de perto, em apartado, embora ela integre o pacote protetivo que estamos analisando.

\section{C) Confidencialidade}

Reportar uma conduta inapropriada na organização, na maioria das vezes, significa quebrar uma rígida linha hierárquica e agir contra os interesses das autoridades, o que coloca quem reporta em uma posição extremamente vulnerável. O mínimo - e mais coerente - que se deve fazer em relação àquele que decide romper o tradicional código de silêncio é resguardar a sua identidade, dando confidencia-

Conselho Europeu (Resolução n. 1.729, de 2010, item 6.3), e pela OCDE (OECD, Commiting to Efective Whistleblower Protection, 2016, p. 65).

195 O projeto de lei n. 3.165/2015, do Deputado Onyx Lorenzoni, ao instituir o Programa de Incentivo à Revelação de Informações de Interesse Público, sugere a aplicação do programa de proteção de vítimas e testemunhas, da Lei n. 9.807/99, que no art. 7o, traz diversas medidas protetivas. Me parece que não é o melhor caminho a ser trilhado, tendo em vista as diferenças evidentes entre os institutos. No caso, a possibilidade de aplicação do programa de proteção às testemunhas somente é possível no âmbito judicial-criminal, ou seja, quando já deflagrado o processo jurisdicional penal. Ocorre que os reportantes, na maioria das vezes, não pode esperar que a questão objeto da denúncia seja levada ao Poder Judiciário para receber a tutela necessária, pois grande parte das retaliações ocorrem no âmbito laboral, bem antes do ingresso na via judiciária. 
lidade ao relato. Tal medida, a propósito, tem fundamento constitucional no direito de acesso à informação, cuja fonte deve manter-se em sigilo (art. 5 $\mathrm{XIV}$, da $\mathrm{CRFB} / 88$ ).

Garantir que as vias de denúncia são seguras, e que a informação revelada será tratada de forma profissional, proporciona ao indivíduo alguma conviç̧ão de que não sofrerá danos pelo simples fato de ter reportado condutas impróprias. $\mathrm{O}$ sistema de proteção como um todo depende dessa segurança: se a confidencialidade é assegurada de forma adequada, é possível que nenhuma outra proteção seja sequer necessária.

A princípio, é preciso ter em mente uma diferenciação relevante para fins de proteção, não confundindo confidencialidade com anonimato. Enquanto no primeiro caso, os dados do indivíduo que revela as informações são de conhecimento da autoridade receptora, porém mantidos em sigilo enquanto não sobrevier situação excepcional que justifique o respectivo levantamento, no segundo, ninguém sabe a fonte do relato, nem quem o recebe. $\mathrm{O}$ anonimato, embora possa fomentar à formulação de denúncias, dificulta a avaliação da credibilidade, assim como pode desviar o foco do conteúdo da denúncia à identidade do reportante, ${ }^{196}$ razão pela qual, tanto no Brasil, como em outros países, as informaçóes provenientes de fontes anônimas (denúncia apócrifa) não tem um valor probatório significativo, sequer possibilitando, por si só, a instauração de inquéritos policiais, sem que sejam precedidas de investigações preliminares. ${ }^{197}$

Assim, a questão quanto à inclusão ou não de relatos anônimos no sistema de assistência e proteção deve ser cuidadosamente examinada. Embora ambas as formas de denúncia sejam utilizadas em vários países, não há um consenso a esse respeito: na legislação australiana (Seção n. 28, da Lei de Proteção a Revelações Públicas), por exemplo, permite-se que revelaçôes de interesse público sejam feitas anonimamente, de forma escrita ou oral. Na Eslovênia, a Comissão de Prevenção da Corrupção trata igualmente todos os relatos, independentemente do conhecimento sobre os dados do informante. Noutro giro, não há previsão para relatos anônimos no Canadá, de modo que, para desencadear as medidas de proteção estabelecidas na lei, funcionário ou empregado deve ser identificável. Chile, França, Itália, Bélgica e Israel também não enquadram reportes anônimos no programa

196 OCDE (2016). Commiting to effective whistleblower protection. OECDpublishing. Disponível em: <https://read.oecd-ilibrary.org/governance/committing-to-effective-whistleblower-protection_9789264252639-en\#page2>. Acesso em: 29 maio 2017, p. 62.

197 Vide STF, Inq. 1957-7/PR, Rel. Min. Carlos Velloso, j. 11.05.2005. 
destinado aos Whistleblowers, ${ }^{198}$ embora não excluam a possibilidade de que denúncias anônimas sejam formuladas e dirigidas a outros órgãos de controle, que as investigarão da forma adequada.

De qualquer modo, a proteção da identidade é essencial à obtenção de dados e à incolumidade do noticiante. ${ }^{199}$ A legislação protetiva da Malásia é um bom exemplo: nas seções 1 a 8 da Lei de Proteção ao Whistleblower, de 2010, as informações consideradas confidenciais incluem: 1) dados sobre a identidade, ocupação, endereço residencial e endereço funcional: do reportante e da pessoa contra quem o reportante fez revelações de condutas impróprias; 2) informação revelada pelo reportante; 3 ) informações que, se reveladas, podem causar prejuízos a qualquer pessoa. $^{200}$

Por outro lado, o resguardo da identidade certamente exigirá um trabalho sério e imparcial das autoridades que são responsáveis por receber os relatos e zelar pela confidencialidade. A confiança na integridade desse sistema - principalmente dos canais internos - será alcançada mediante a previsão de ferramentas disciplinares que reforcem o dever de proteção à identidade. Em vista disso, alguns países preveem sançôes severas no caso de quebra da confidencialidade. Na Coreia do Sul, qualquer pessoa que revele informações pessoais sobre o informante, ou fatos dos quais possa-se deduzir a sua identidade, será punida com reclusão de até 3 anos ou multa de 30 milhões de wons sul-coreanos, equivalente a cerca de $\mathrm{R} \$ 88.000,00 .^{201}$

Como qualquer elemento de proteção, a confidencialidade deve ter limitações claras, e os reportantes devem conhecê-las. Primeiro, as limitações naturais: por exemplo, deve ser explicado que a garantia de não revelação da identidade não impede que outros presumam qual seja a fonte da informação, ou que, pelas circunstâncias, seja possível identificar quem reportou determinada conduta. Se somente um agente tinha condições de saber sobre certos comportamentos, e logo

198 OCDE. Survey on managing conflict of interest in the executive branch and whistleblower protection. Paris, 2014.

199 A Suprema Corte dos Estados Unidos, no caso State of New Jersey v. Sean Mcardle: "o propósito da prerrogativa [de preservar a identidade do informante] tem duas finalidades: proteger a segurança do informante e encorajar o processo de informação' (State v. Sessons, 423 N.J. Super. 338, 343. App. Div. 2010).

${ }^{200}$ Laws of Malaysia. Act 711. Whistleblower protection act 2010. Part III, Section 8. Disponível em: <http://www.bheuu.gov.my/pdf/Akta/Act\%20711.pdf>. Acesso em: 29 maio 2017.

201 The United Nations Convention against corruption: resource guide on good practices in the protection of reporting persons. Nações Unidas, 2015, p. 39. 
depois as informações chegam ao conhecimento do órgão de controle, os infratores certamente saberão quem soou o alarme. E também as limitações legais, permitindo o levantamento, mediante decisão judicial fundamentada, quando a situação denunciada não puder ser resolvida sem que a fonte original da informação seja previamente ouvida, como nos casos em que o relato envolve situaçôes de perigo iminente à coletividade, ou quando for necessário ao prosseguimento de uma investigação criminal. ${ }^{202}$

Fora estas hipóteses excepcionais, o sigilo deve ser mantido, perdurando inclusive após o início de eventual processo judicial relacionado à denúncia. Nos Estados Unidos, a confidencialidade nesta fase é vista como um privilégio do informante (confidential informant privilege) e direito do Estado, vez que utiliza das informações reportadas. ${ }^{203}$ Reconhece-se, entretanto, que as cortes de justiça devem ponderar o interesse público em resguardar a identidade do reportante, em vista da necessidade do denunciado de conhecer a fonte de informação para formular a defesa nos autos. Existe uma grande controvérsia neste sentido, principalmente no âmbito da justiça criminal, a respeito da admissibilidade ou não de fontes confidenciais no processo, diante do chamado direito à confrontação (right of confrontation). Não é algo que pretendo aprofundar neste espaço. Me parece que a melhor forma de resolver este conflito passa por uma análise individualizada do caso, para que os interesses dos reportantes não sejam injustificadamente colocados em perigo, como afirmou a Corte Europeia de Direitos Humanos, no caso Doorson v. The Netherlands, julgado em 26 de março de $1996 .{ }^{204}$

202 Previsão semelhante encontra-se em vigor nos Estados Unidos, onde se proíbe a revelação de informaçōes sobre a identificação do reportante sem o seu consentimento prévio, exceto se o Office of Special Counsel (OSC), órgão responsável pelo recebimento e investigação dos relatos no âmbito do setor público federal, "determine que a revelação da identidade do indivíduo seja necessária devido a um dano iminente à saúde ou segurança pública ou iminente violação de qualquer lei criminal". (U.S. Whistleblower Protection Act, 1989; 5. USC. $\$ 1213(\mathrm{~h})$.

203 DALLAGNOL, Deltan Martinazzo. Informantes confidenciais e anônimos: perspectivas para atuação mais eficiente a partir de uma análise comparativa do tratamento jurídico nos EUA e no Brasil. In: Ministério Público e princípio da proteção eficiente. São Paulo: Almedina, 2016.

${ }^{204}$ Outra solução interessante foi delineada pelo Tribunal de Recursos Trabalhistas do Reino Unido, no caso Linfood Cash and Carry Ltd $v$. Thompson (1989) que, dentre outras formas de balancear o direito à confrontação com a proteção da identidade, determinou a transcrição das informações relatadas, fornecendo declaraçóes escritas ao acusado, caso o reportante confirmasse que não estava preparado para comparecer à audiência. 
-• Finanças públicas: travessia entre o passado e o futuro

D) Sistema de recompensas

Em adição ao estigma que pode resultar do ato de assoprar o apito, os reportantes também podem se deparar com graves perdas financeiras. De modo a tentar reduzir esses prejuízos e encorajar indivíduos a dar o passo à frente na detecção de más condutas, alguns países têm introduzido, além das medidas protetivas, incentivos que vão desde o reconhecimento em tokens de apreciação, na Indonésia, ${ }^{205}$ até vultuosas recompensas monetárias, nos Estados Unidos e Coreia do Sul.

Um sistema de prêmios e recompensas àqueles que denunciam atos de corrupção não é um elemento imprescindível ao funcionamento do programa em geral, mas as retribuições estimulam bastante a formulação dos relatos de interesse público. "Dizer que nunca pensei no retorno financeiro seria um absurdo", foi o que disse Pat Shull, que recebeu US \$ 25 milhões como resultado da revelação de ilegalidades no Banco da América (Bank of America), em 1998. A controvérsia é grande.

Os apelidos (caçador de recompensa, deduragem remunerada, snitch), em tom de crítica, direcionados ao reportante, decorrem principalmente deste elemento. A previsão de recompensas acaba gerando dúvidas quanto à intensão de quem relata condutas irregulares. Muitos acreditam que a revelação de corrupção teria que partir de uma obrigação ou dever ético, não devendo estar vinculada à expectativa futura de recompensa financeira, sob pena de fustigar a legitimidade de todo o instrumento. Por outro lado, afirma-se que seria imoral retribuir o denunciante com valores que constituem produto da corrupção, o que equivaleria, indiretamente, a um desvio-duplo do dinheiro originalmente público.

Mesmo assim, um número considerável de países institui pagamentos em contrapartida à apresentação de evidências relevantes para apuração de irregularidades e restituição de valores desviados. Nesses lugares, lançar o alerta sobre a corrupção, além de auxiliar na investigação de condutas impróprias, tornou-se um grande negócio. Um exemplo amplamente reconhecido e eficaz é aquele empregado nos Estados Unidos, pelo programa de relatos da Comissão de Valores Mobiliários (Securities and Exchange Comission - SEC), em conformidade com a Lei Dodd-Frank, de 2010, que oferece recompensa financeira em troca de informações originais e relevantes que auxiliem na aplicação da lei. $\mathrm{O}$ montante da premiação é determinado de acordo com o montante recuperado pelas autoridades da

${ }^{205}$ Lei n. 31, de 1999, pela Erradicação dos atos Criminais de Corrupção. Artigo 42. 
Comissão, como resultado dos procedimentos iniciados com base na informação reportada, e limita-se à faixa de 10 a 30\% da sanção aplicada pela SEC, desde que o valor objeto do relato ultrapasse a faixa de US\$ 1 milhão.

Desde a criação desse programa especial para whistleblowers, em 2011, a SEC premiou 43 denunciantes, num valor total de aproximadamente US\$ 153 milhôes. ${ }^{206}$

O sistema de premiação também é previsto em outras leis americanas. Pelo False Claims Act, cuja aplicação é restrita a fraudes relacionadas a contratos governamentais, indivíduos podem prestar queixas sobre corrupção em nome do estado, e receber até $30 \%$ do valor eventualmente recuperado. Além do mais, o programa de proteção aos reportantes da Receita Federal Americana (Internal Revenue Service - IRS), ${ }^{207}$ que possui uma secretaria específica para relatos internos (Whistleblower Office), paga àqueles que relatam sonegações fiscais e outras fraudes tributárias, entre 15 a 30\% do montante restituído, incluindo multa, juros e correçôes, caso este ultrapasse US $\$ 2$ milhōes. Somente no ano fiscal de 2013, o total de premiações pagas a denunciantes superou os US\$ 53 milhões, representando apenas $14,6 \%$ do total de recursos recuperados em virtude dos relatos. ${ }^{208}$

O modelo legal proposto pela Convenção Interamericana Contra a Corrupção (art. 15), prevê que as autoridades competentes devam fornecer benefícios econômicos a denunciantes de condutas irregulares, cujas informaçôes tornem possível a restituição ao erário, embora não sugira um percentual específico. A convenção somente faz uma ressalva em relação aos reportantes que sejam agentes governamentais, os quais deveriam receber benefícios de natureza não financeira.

Embora consolidado nos Estados Unidos, e aplicado com sucesso em outros países, como Coreia do Sul, ${ }^{209}$ tal sistema de incentivos econômicos não é

206 CASSIN, Richard L. SEC whistleblower awarded nearly \$4 million. The FCPA Blog. Disponível em: <http://www.fcpablog.com/blog/2017/4/25/sec-whistleblower-awarded-nearly-4-million.html>. Acesso em: 25 abr. 2017.

207 U.S. Code. Title 26. Subtitle F. Chapter 78. Subchapter B. \$ 7623, b.1.

${ }^{208}$ Internal Revenue Service Fiscal Year 2013. Report to the Congress $n$ the Use of Section 7623, p. 23. Disponível em: <www.irs.gov/pub/whistleblower/Whistleblower_Annual_report>. Acesso em: 30 maio 2017.

${ }^{209}$ Conforme a Lei Anticorrupção, que entrou em vigor em outubro de 2015, a Agência Anticorrupção (ACRC) oferecerá um máximo de aproximadamente 2,6 milhōes de dólares (3 bilhōes de wons coeranos), para reportantes que diretamente contribuírem à recuperação de valores às agências públicas. Também provê um máximo de aproximadamente 170 mil dólares (200 milhóes de wons coreanos) a reportantes que se considera terem contribuído para o 
unanimidade entre os modelos adotados mundo afora. Dos países integrantes da OCDE, 70\% não preveem premiações ou incentivos à revelação de informações por reportantes. ${ }^{210}$

Multiplicam-se as críticas às formas de pagamento por relatos de corrupção. Um estudo realizado por instituições britânicas sobre o sistema americano de recompensa, concluiu que estímulos financeiros não aumentam o número de denúncias, tampouco servem para melhorar a transparência e a integridade das organizações, pois o sistema paga muito para poucos informantes, além do fato de que as recompensas podem colocar em risco os programas de compliance das empresas, pois desmotiva a utilização de canais internos. ${ }^{211}$

Uma via alternativa à compensação financeira do relato, é a previsão de benefícios não econômicos, de caráter mais simbólico, que reconheça publicamente a atitude do reportante, dando-lhe méritos pela proteção do interesse coletivo. É o que acontece, por exemplo, em Israel, onde se prevê a emissão de um certificado de reconhecimento público, entregue pelo Presidente, como símbolo da contribuição do indivíduo ao aprimoramento ético das instituições israelitas. ${ }^{212}$

Trazer esta discussão para o Brasil é desafiadora e perigosa, considerando o alto grau de polarização na sociedade. O bom-senso parece ter saído de moda, dando lugar à irracionalidade e aos argumentos de autoridade. É muito provável que um debate sobre a possibilidade de recompensa monetária dos denunciantes rapidamente se converta numa exclamação simplista de que se está oficializando o papel do dedo-duro remunerado no país. Espero que isso não aconteça. Se optarmos ou não por conferir prêmios à virtude daqueles que relatam a corrupção, que o debate seja racional e não ignore a questão principal, que consiste na proteção destes cidadãos reportantes.

Decidindo adotar um modelo de incentivos financeiros aos reportantes, este deve ser visto como complementar à proteção, e não como uma peça-chave do

enfrentamento da corrupção no setor público. No setor privado, a Lei de Revelações de Interesse Público prevê recompensa de até 1.7 milhōes de dólares a reportantes internos. (OCDE. Commiting to effective whistleblower protection, 2016, p. 67).

210 OCDE. Survey on managing conflict of interest in the executive branch and Whistleblower Protection. Paris, 2014.

211 BANK OF ENGLAND. Prudential regulation authority. financial incentives for whistleblowers: note by the financial conduct authority and the prudential regulation authority for the treasury Select Committee, 2014.

212 OCDE. Commiting to effective whistleblower protection, 2016, p. 62. 
sistema, assim como tem de ser criterioso na concessão dos benefícios. Qualquer premiação cogitada deve levar em conta a qualidade da informação fornecida, ou seja, se ela revela práticas graves relacionadas à corrupção, fraude, desperdícios, má-gestão e se as informações são originais. ${ }^{213}$

Existem múltiplas formas de encorajar a prevenção e detecção de más condutas. Essas medidas podem contribuir para a consolidação de uma cultura organizacional aberta, bem como ajudariam a reforçar a confiança e a moralidade nas instituições.

213 O modelo legal proposto pela Convenção Interamericana Contra a Corrupção, no art. 28, prevê alguns critérios de avaliação da relevância da informação. De acordo com este documento, a informação fornecida pelo reportante deve ser considerada relevantes caso permita à autoridade judicial ou administrativa alcançar pelo menos um dos seguintes resultados: a) prevenir a continuação, existência, completude do ato de corrupção, o reduzir substancialmente as consequências de sua execução; b) prevenir ou neutralizar futuros atos de corrupção; c) identificar as circunstâncias nas quais o ato de corrupção foram planejados e executados; d) identificar os executores dos atos de corrupção que foram ou estão prestes a serem cometidos, ou os membros da organização criminosa e suas operaçōes, tornando possível desmantelar, enfraquecer ou prender um ou mais de seus membros; e) identificar o propósito ou destinação dos bens, efeitos e procedimentos do ato de corrupção. 
